\title{
The Bioactivity and Phytochemicals of Pachyrhizus erosus (L.) Urb.: A Multifunctional Underutilized Crop Plant
}

\author{
Varun Jaiswal ${ }^{1,+}\left(\mathbb{D}\right.$, Shweta Chauhan ${ }^{1,+}$ and Hae-Jeung Lee $1,2,3, *$ (D) \\ 1 Department of Food and Nutrition, College of BioNano Technology, Gachon University, \\ Seongnam-si 13120, Korea; computationalvarun@gmail.com (V.J.); chauhanshweta210@yahoo.com (S.C.) \\ 2 Institute for Aging and Clinical Nutrition Research, Gachon University, Seongnam-si 13120, Korea \\ 3 Department of Health Sciences and Technology, GAIHST, Gachon University, Incheon 21999, Korea \\ * Correspondence: skysea@gachon.ac.kr or skysea1010@gmail.com \\ + These authors contributed equally to this work.
}

Citation: Jaiswal, V.; Chauhan, S.; Lee, H.-J. The Bioactivity and Phytochemicals of Pachyrhizus erosus

(L.) Urb.: A Multifunctional

Underutilized Crop Plant.

Antioxidants 2022, 11, 58. https://

doi.org/10.3390/antiox11010058

Academic Editor: Julia

González-Álvarez

Received: 22 November 2021

Accepted: 22 December 2021

Published: 27 December 2021

Publisher's Note: MDPI stays neutral with regard to jurisdictional claims in published maps and institutional affiliations.

Copyright: (C) 2021 by the authors. Licensee MDPI, Basel, Switzerland. This article is an open access article distributed under the terms and conditions of the Creative Commons Attribution (CC BY) license (https:// creativecommons.org/licenses/by/ $4.0 /$ )

\begin{abstract}
Pachyrhizus erosus (L.) Urb. is an underutilized crop plant belonging to the Fabaceae family. In recent years, the plant received huge attention and was introduced in different countries owing to properties such as a high nutritional content, its nitrogen-fixing abilities, and different biological activities such as its antioxidant, immune modulation, anticancer, anti-diabetes, antiosteoporosis, antiviral, and antiaging affects, among others. In this review, an attempt has been made to comprehensively compile the biological activities of the plant to provide a panoramic view of the current efforts and further directions, which may lead to the development of pharmacological applications. This information will be helpful in creating interest towards P. erosus and it may be useful in developing the plant for medical applications and/or as a functional food. More than 50 phytochemicals have been reported from the plant, which belong to different chemical classes such as triterpenoids, organic acid, flavonoids, and fatty acids. Numerous biological activities were reported from the plant through in vivo, in vitro, ex vivo, and human studies. However, well-defined clinical studies are still lacking for the establishment of any biological properties that could be further developed. Suggestions for the further development of P. erosus, according to current knowledge about the different biological properties, has also been provided.
\end{abstract}

Keywords: antioxidants; flavonoids; Pachyrhizus erosus; jicama; phytochemicals; pharmacological activities; anticancer; anti-diabetes

\section{Introduction}

The positive roles of antioxidant and immune modulation properties against infectious, as well as non-infectious, diseases have emphasized the importance of dietary plants with these properties [1-3]. Pachyrhizus erosus (P. erosus) is primarily a crop plant, which is underutilized in different parts of the world despite having a high nutritional content. Like the traditional medicinal plants, it is used in folk medicine and is known for its antioxidant properties [4-8]. Different parts of the plant have pharmacological and health-promoting properties, which have the potential to be utilized in different biological activities and diseases, such as antioxidants, immune modulation, anti-aging effects, diabetes, cancer, osteoporosis, and viral and fungal diseases [6,9-17].

P. erosus is also known as jicama, yam bean, Mexican turnip, shankhalu (in Bengali), singkamas (in the Philippines), kuzu-imo (in Japan) and bang kuang (in Korea and China).

P. erosus originated from the semiarid tropics of Central America and Mexico, and from there the cultivation of P. erosus expanded into different parts of the world, such as the Philippines, Indonesia, Malaysia, Vietnam, Laos, Thailand, Taiwan, Cambodia, Singapore, Burma, China, and India. In the recent past, P. erosus was introduced into South Korea [18-20]. Considering its high nutrient content and nitrogen-fixing properties, P. erosus was also introduced into the African countries with the objective to complement food sources and improve the 
sustainability of the farming structure so that it might overcome food insecurity. It can also counter malnutrition found in children under five years [21] in some African countries, and is mainly endorsed due to the extra dependency on the popular tuber and root crops, such as sweet potato, potato, and cassava, which have limited sources of absorbable micronutrients and proteins.

P. erosus is still an underutilized crop, but due to its high nutrient content, its nitrogenfixing properties for sustainable farming, its different pharmacological properties, and the successful introduction of $P$. erosus in different countries around the world, the production of $P$. erosus is expected to grow in the near future. It can produce heavy storage roots compared to other comparable root crops, such as cassava (Manihot esculenta), as well as having several times more protein content [22].

The seeds of P. erosus are toxic due to the presence of rotenone. Rotenone is considered as a moderately toxic compound for humans by the World Health Organization. The ingestion of seeds can cause severe toxicity, which may lead to death [23-26]. Therefore, the seeds cannot be consumed directly. However, the use of P. erosus in folk medicine has been reported $[8,27]$. Therefore, researchers have explored the presence of dietary fiber, protein, carbohydrates, inulin, vitamin $C$, folates, riboflavins, pyridoxine, pantothenic acid, thiamin, and other phytochemicals in the tubers of P. erosus, which has provided the basis of its pharmacological potential [6,9-17]. Similarly, the seeds and leaves are also rich in different phytochemicals, which further encourages researchers to develop natural drugs and cosmetics $[4,9,10,13]$. Numerous studies have reported the potential application of $P$. erosus in a number of diseases, as well as immune enhancement, which not only suggests the potential of the plant to be developed as a medicinal plant but also shows it as an underutilized crop. Although the increased production of P. erosus is expected in the near future, a comprehensive compilation of its pharmacological properties and phytoconstituents is missing for the plant in the literature. The current review is an attempt to assemble the information of phytochemicals and biological activities of different parts of this perennial plant, which may pave the way for the development of a natural pharmacological intervention for different diseases, as well as promoting health and improving cosmetics.

\section{Electronic Literature Search}

An extensive literature search was carried out through online databases, such as PubMed, Scopus, Google Scholar, Google, and ReseachGate. It included important keywords and their combinations according to previous studies, such as Pachyrhizus erosus, jicama, yam bean, Mexican turnip, kuzu-imo, bang kuang, nutrient composition, phytochemical composition, pachyrhizus and biological activity, Pachyrhizus erosus and cancer, P. erosus and review, etc., which were used for the literature search. The resulting research articles, review articles, books, and theses until 2021 were explored and the important literature was included in the current study.

\section{Botanical Description}

P. erosus is a perennial vigorous climbing herb that belongs to the Fabaceae family. The plant grows in a warm, humid, and tropical climate from sea level to $1400 \mathrm{~m}$ above sea level, with an optimal temperature range of 20 to $28^{\circ} \mathrm{C}$ in areas with moderate rainfall, that is, with an average annual rainfall of about $1500 \mathrm{~mm}$. It prefers full sunlight and saturated, moist, well-drained, light, sandy loam, as well as alluvial or volcanic soils. It can produce annual stems 2-6 m long from a tuberous root stock. The root can weigh up to $20 \mathrm{~kg}$. It has been reported that the formation of flowers and tubers occurs almost simultaneously during the development of the plant [19]. It is a herbaceous vine that has compound leaves of a dark green color with a wide variety of leaf shapes, from serrated to serrated fingered. P. erosus produces bisexual flowers $1-2.5 \mathrm{~cm}$ long which are self-pollinating in nature. Flowering begins 58-68 days after sowing and lasts 92-103 days. It was found that the stigma becomes receptive at $12 \mathrm{~h}$ before the opening of the flower, and lasts for $18 \mathrm{~h}$ after 
opening. The appearance is determined by the absence of hairs on the petals, the number of flowers (4-11) on the lateral axis of the inflorescence, i.e., complex racemes, and the length of the inflorescence, which is between 8 and $45 \mathrm{~cm}$. In addition, the morphological features of the legumes (pods), both qualitative and quantitative, are used to separate the species. The size $(6-13 \mathrm{~cm} \times 8-17 \mathrm{~mm})$ and reduction of strigous hairs with maturation and color (from pale brown to olive green/brown) are characteristic of $P$. erosus legumes. The seed characters are also specific; they include a color that varies from olive green to brown or reddish-brown, and the shape is flat and square to round, but never reniform [19].

\section{Nutritional Composition}

Primarily, the tuber of P. erosus is used for consumption, as the food consists of the underground roots, whereas the seeds of the plant are considered toxic because of the presence of rotenone, which may cause death [23-26]. Researchers have been also trying to harvest the potential of the seeds to consume as food, due to their high protein and lipid content $[28,29]$.

\subsection{The Nutritional Composition of the Tuber}

The high nutritional components and low anti-nutritional factors show the usefulness of the tuber of P. erosus in malnourished regions of the world [30]. The nutritional composition of the tuber may vary according to the form which is consumed, such as its flour, the raw tuber, or its juice. The harvest time can also change the nutritional composition of the tuber [30]. The nutritional composition also depends on the environmental conditions of the surroundings of the plant, and small changes are expected in different studies.

In a study conducted on the fresh tuber, the $P$. erosus tuber had the highest percentage of moisture $(82.01 \pm 2.24)$, reducing sugar $(1.83 \pm 0.22)$, and crude fiber $(1.4 \pm 0.14)$, and the lowest content of starch $(9.04 \pm 0.11)$, sucrose $(3.24 \pm 0.13)$, carbohydrate $(14.9 \pm 0.04)$, total soluble sugar $(2.13 \pm 0.11)$, energy $(39 \pm 1.23 \mathrm{Kcal} / 100 \mathrm{gm})$, and ash $(0.5 \pm 0.12)$ in comparison with the potato and sweet potato. The lipids $(0.1 \pm 0.04)$ and high protein $(1.23 \pm 0.13)$ content was also observed in the tuber [30].

Furthermore, vitamins such as ascorbic acid $(14 \pm 0.1 \mathrm{mg} / 100 \mathrm{~g})$, thiamine $(0.05 \pm$ $0.001 \mathrm{mg} / 100 \mathrm{~g})$, riboflavin $(0.02 \pm 0.002 \mathrm{mg} / 100 \mathrm{~g})$, pyridoxine $(0.25 \pm 0.01 \mathrm{mg} / 100 \mathrm{~g})$, niacin $(0.2 \pm 0.01 \mathrm{mg} / 100 \mathrm{~g})$ and folic acid $(0.001 \pm 0.0002 \mathrm{mg} / 100 \mathrm{~g})$ were also identified in the tuber. The contents of important minerals such as $\mathrm{Ca}(16 \pm 0.45 \mathrm{mg} / 100 \mathrm{~g}), \mathrm{Cu}$ $(0.048 \pm 0.01 \mathrm{mg} / 100 \mathrm{~g})$, Fe $(1.4 \pm 0.03 \mathrm{mg} / 100 \mathrm{~g}), \mathrm{Mg}(12.9 \pm 1.05 \mathrm{mg} / 100 \mathrm{~g}), \mathrm{Mn}(0.06 \pm$ $0.002 \mathrm{mg} / 100 \mathrm{~g}), \mathrm{P}(18 \pm 1.02 \mathrm{mg} / 100 \mathrm{~g}), \mathrm{K}(172 \pm 3.14 \mathrm{mg} / 100 \mathrm{~g}), \mathrm{Na}(35 \pm 1.23 \mathrm{mg} / 100 \mathrm{~g})$, $\mathrm{Zn}(0.16 \pm 0.02 \mathrm{mg} / 100 \mathrm{~g})$, and Se $(0.7 \pm 0.07 \mu \mathrm{g} / 100 \mathrm{~g})$ were also calculated in the tuber of P. erosus.

Ten essential and seven non-essential amino acids were detected in the tuber and the content of essential and non-essential amino acids was found to be 12.14 and $28.84 \mu \mathrm{M} / \mathrm{gm}$, respectively [30].

\subsection{The Nutritional Composition of the Seeds}

$P$. erosus seeds are toxic due to the presence of rotenone; therefore, they cannot be consumed directly. However, high contents of proteins, lipids, Fe, and Ca are observed in the seeds as compared to other legume plants. A study showed that the amino acid (isoleucine, leucine, lysine, methionine, phenylalanine, tyrosine, threonine, valine, and histidine) composition had a better balance of essential amino acids compared to other seeds and concluded that $P$. erosus seeds could be a good source of highly nutritional quality proteins [31]. Different mitigation strategies have been studied for the degradation of rotenone in the seeds, which include drying, roasting, boiling, frying, and alcohol extraction. Drying and roasting were found to be most efficient methods for the degradation, which can degrade up to $80 \%$ of rotenone in the seeds [29]. However, the potential for the consumption of the seeds remains very limited, as a rotenone level in the seeds of P. erosus 
did not go into the safe range. In future studies, the combination of different methods may be helpful to reduce the rotenone to safe levels [29].

P. erosus seeds, on a wet basis, was analyzed by researchers for their proximate composition, minerals, protein fractions, antinutritional factors, and rotenoids [28]. The seeds showed a high content of protein $(28.27 \mathrm{~g} / 100 \mathrm{~g})$, lipids $(26.8 \mathrm{~g} / 100 \mathrm{~g})$, ash $(4.58 \mathrm{~g} / 100 \mathrm{~g})$, crude carbohydrate $(26.85 \mathrm{~g} / 100 \mathrm{~g})$, fiber $(6.2 \mathrm{~g} / 100 \mathrm{~g})$ and moisture content $(7.30 \mathrm{~g} / 100 \mathrm{~g})$ [28]. The oil content of the seed was reported to be around $20.5 \%$ to $28 \%$, which constituted of palmitic $(26.7 \%)$, stearic $(5.7 \%)$, oleic $(33.4 \%)$, linoleic $(34.2 \%)$, and linolenic (in trace amount) acids [32]. The researchers suggested that the oil could be used in the edible oil industry as a vegetable/cottonseed oil [32]. The quantification of fatty acids in comparison with the other species of the genus Pachyrhizus was done in 1999, which showed a total protein content of $29.9 \%$ of the seed weight. The fatty acid content was $24 \%$ and was found to be made up of palmitic acid $(27.8 \%)$, stearic acid $(4.5 \%)$, oleic acid $(25.4 \%)$, linoleic acid $(37.0 \%)$, and linolenic acid $(1.3 \%)$. The total amount of tocopherols was found to be $443.7 \mathrm{mg} / \mathrm{kg}$, which constituted of $\alpha$-tocopherol (4.8\%), $\gamma$-tocopherol (94.5\%), and $\delta$-tocopherol (0.7\%) [33]. The presence of high levels of palmitic acid with low levels of linolenic acid in the seed suggested this as an alternative source of palmitic acid oil in the food industry [33]. A recent study has also shown that the methyl esters of P. erosus seed oil can be used as biodiesel in warmer climate countries [34]. While the seeds are rich in protein and fat, they also contain different important minerals. The mineral composition of P. erosus is Ca $(356.0 \mathrm{mg} / 100 \mathrm{~g})$, Fe $(16.0 \mathrm{mg} / 100 \mathrm{~g})$, $\mathrm{K}(992.0 \mathrm{mg} / 100 \mathrm{~g}), \mathrm{P}(286.0 \mathrm{mg} / 100 \mathrm{~g}), \mathrm{Na}(6.8 \mathrm{mg} / 100 \mathrm{~g}), \mathrm{Cu}(1.2 \mathrm{mg} / 100 \mathrm{~g})$, and Zn $(4.0 \mathrm{mg} / 100 \mathrm{~g})[28]$.

\subsection{The Nutritional Composition of Seed Flour}

The seeds showed a high content of protein $(51.20 \mathrm{~g} / 100 \mathrm{~g})$, lipids $(1.51 \mathrm{~g} / 100 \mathrm{~g})$, ash $(3.64 \mathrm{~g} / 100 \mathrm{~g})$, crude carbohydrate $(35.78 \mathrm{~g} / 100 \mathrm{~g})$, fiber $(4.42 \mathrm{~g} / 100 \mathrm{~g})$, and moisture content $(3.45 \mathrm{~g} / 100 \mathrm{~g})$ [28]. The composition of essential amino acids included isoleucine $(4.4 \pm 0.16 \mathrm{~g} / 100 \mathrm{~g})$, threonine $(3.5 \pm 0.07 \mathrm{~g} / 100 \mathrm{~g})$, phenylalanine $(5.5 \pm 0.38 \mathrm{~g} / 100 \mathrm{~g})$, tyrosine $(3.2 \pm 0.31 \mathrm{~g} / 100 \mathrm{~g})$, valine $(4.6 \pm 0.02 \mathrm{~g} / 100 \mathrm{~g})$, lysine $(6.5 \pm 0.06 \mathrm{~g} / 100 \mathrm{~g})$, histidine $(4.1 \pm 0.37 \mathrm{~g} / 100 \mathrm{~g})$, methionine $(1.4 \pm 0.11 \mathrm{~g} / 100 \mathrm{~g})$, and leucine $(7.7 \pm 0.21 \mathrm{~g} / 100 \mathrm{~g})$. The composition of non-essential amino acids constituted of serine $(4.3 \pm 0.05 \mathrm{~g} / 100 \mathrm{~g})$, aspartic acid $(9.7 \pm 0.08 \mathrm{~g} / 100 \mathrm{~g})$, alanine $(4.0 \pm 0.03 \mathrm{~g} / 100 \mathrm{~g})$, glycine $(3.8 \pm 0.04 \mathrm{~g} / 100 \mathrm{~g})$, arginine $(4.5 \pm 0.20 \mathrm{~g} / 100 \mathrm{~g})$, glutamic acid $(15.8 \pm 0.17 \mathrm{~g} / 100 \mathrm{~g})$, and proline $(4.1 \pm 0102 \mathrm{~g} / 100 \mathrm{~g})$ [28] In the seed flour, the toxic compound rotenone was quantified as $0.06 \mathrm{mg} / 100 \mathrm{~g}$ and anti-nutritional compounds, namely tannins, were found to be $6 \mathrm{mg} / 100 \mathrm{~g}$.

\section{Phytoconstituents}

Researchers have isolated and identified different phytochemicals, mainly from the seeds, tubers, and leaves of $P$. erosus in different studies. In most of the studies, the major motivation behind the phytoconstituent analysis was the possible biological properties of the plant. Therefore, the biological properties of isolated and characterized phytochemicals were also analyzed in most of the studies. Some of the identified phytochemicals were found to be the reason for the biological activity of P. erosus as having anticancer, antifungal, and antiviral properties, among others (discussed in the next section). Most of the phytochemicals from P. erosus can be grouped into the flavonoids category, although other classes of molecules, such as triterpenes, different organic acids, fatty acids, and volatile organic compounds were also characterized from the different parts of the plant in several studies (Table 1 and Figure 1). These studies are discussed in the subsequent text and Table 1. 


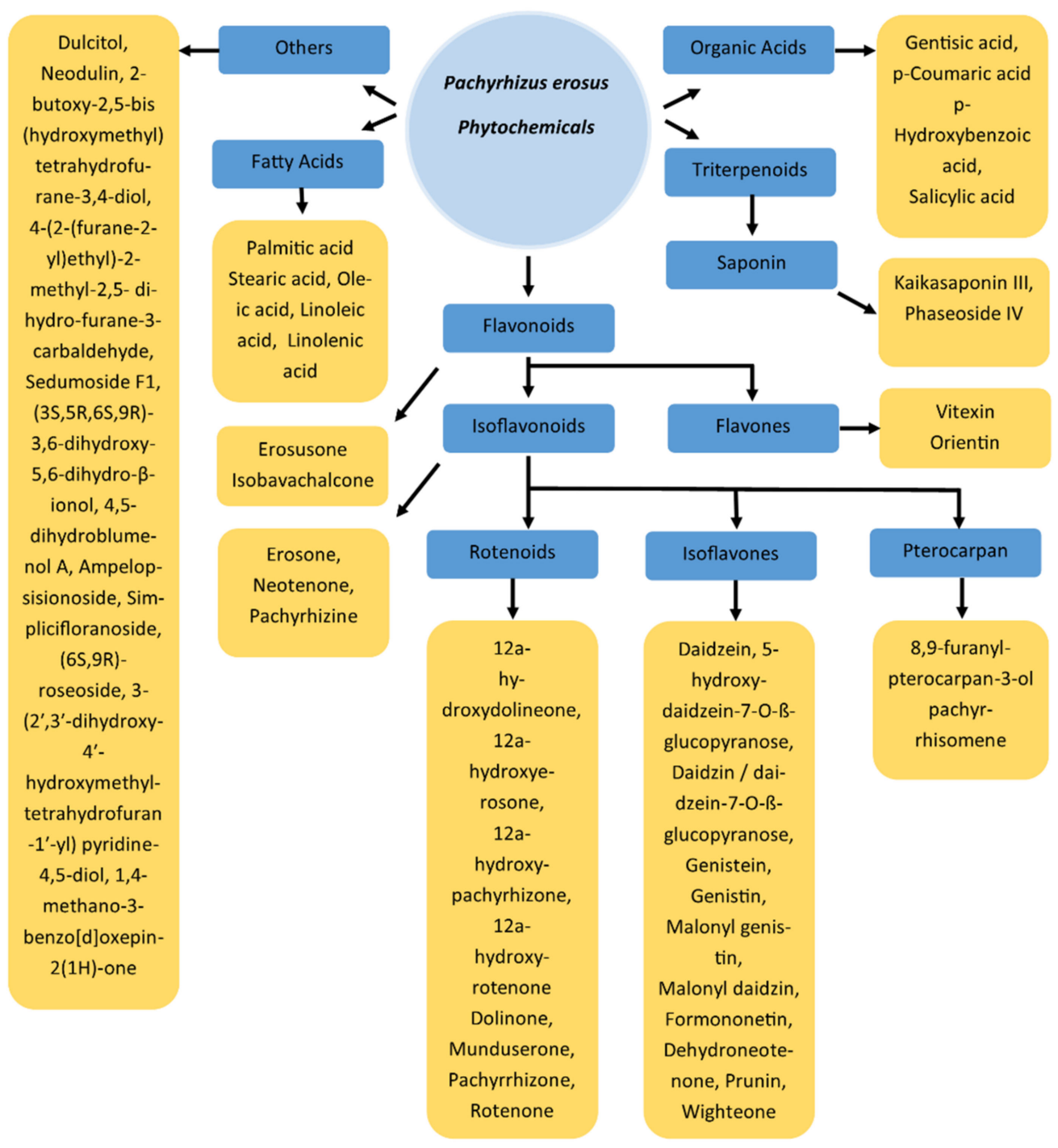

Figure 1. Phytochemicals reported form P. erosus.

In the late 1990s, two triterpenoid glycosides, kaikasaponin III and phaseoside IV, together with daidzin and (+) -abrin, were isolated from the tuber (in both the peel and the flesh) of P. erosus. It was the first study in which both triterpienoids, as well as isoflavonoids, were identified in P. erosus. The proton $(1 \mathrm{H})$ and carbon-13 $(13 \mathrm{C})$ nuclear magnetic resonance (NMR) imaging was used for the spectral characterization of the compounds [35].

Around the same time, using bioactivity-guided fractionation on the seeds of P. erosus, nine isoflavonoids were isolated, including novel compounds such as coumaronochromene and pachyrrhisomene, as well as known compounds such as pterocarpan, neodulin, 3-arylcoumarin, pachyrrhizin, and six known rotenoids, namely rotenone, munduserone, 12a-hydroxyrotenone, 12a-hydroxydolineone, 12a-hydroxypachyrrhizone and 12a-hydroxyerosone. These compounds were characterized through $1 \mathrm{H}$ and 13C NMR imaging [10]. Later, the quantification of pachyrrhine and rotenone in the seeds was validated and the concentration of pachyrhhizin per gram of seeds was found to be in the range of $0.25 \mathrm{mg}$ to $5 \mathrm{mg}$. Rotenone was observed between $0.58 \mathrm{mg} / \mathrm{g}$ and $4 \mathrm{mg} / \mathrm{g}$ [36].

In the early 2000s, researchers explored the seeds of P. erosus for their phytochemicals to investigate their antifungal properties. In the study, they found nine compounds from the seeds which consisted of five rotenoids (dolineone, pachyrrhizone, 12a-hydroxydolineone, 12a-hydroxypachyrrhizone, and 12a-hydroxyrotenone), 
two isoflavonoids (neotenone and dehydroneotenone), one phenylfuranocoumarin (pachyrrhizine), and a monosaccharide (dulcitol) [9].

Later in another study, the seed extract was chromatographed for the isolation of phytochemicals, mainly isoflavonoids, present in the seeds. Five compounds were characterized in the dichloromethane extract, which were rotenone, erosone, pachyrrhizone, dolinone, and pachyrrhizine. One compound, i.e., dehydroneotenone, was isolated from the acetone extract of the seeds. The component identity was determined using UV-Vis, IR, $1 \mathrm{H}$ and 13C NMR [13].

In the search for antioxidants and skin whitening activities of the tuber of P. erosus, researchers identified six active compounds in the ethyl acetate fraction. The identified compounds were daidzein, daidzin, genistin, (8,9)-furanyl-pterocarpan-3-ol, 4-(2-(furane-2yl)ethyl)-2-methyl-2,5-dihydro-furane-3-carbaldehyde, and 2-butoxy-2,5-bis(hydroxymethyl)tetrahydrofurane-3,4-diol [37].

In another study by Lukitaningsih and Holzgrabe in 2014, three isoflavonoids (daidzein, daidzein-7-O- $\beta$-glucopyranose, 5 -hydroxy-daidzein-7-O- $\beta$-glucopyranose), and a new pterocarpan (8,9-furanyl-pterocarpan-3-ol) with antioxidant activities were reported from the tuber of P. erosus [6]. Furthermore, in an HPLC-based method, the concentrations of daidzein and genistein were found to be 110.454 and $165.530 \mathrm{mg} / 100 \mathrm{~g}$, respectively, in the tuber.

Later, researchers again isolated four isoflavonoids, i.e., rotenone, dolineone, 12ahydroxypachyrhizone, and pachyrizine through column chromatography from the acetone extract of P. erosus seeds. The reported yields were $0.01 \%, 0.006 \%, 0.004 \%$, and $0.006 \%$ for rotenone, dolineone, 12a-hydroxypachyrhizone, and pachyrizine, respectively [38].

In a recent study, the methonolic extract of the leaves of P.erosus was used for the isolation and identification of phytochemicals. In this study, two new compounds, erosusone (prenylated chalcone) and 3-episedumoside $\mathrm{F}_{1}$ (megastigmane glycoside epimer), along with 13 known compounds were found [39]. The other known compounds were five flavonoids (isobavachalcone, vitexin, wighteone, pruning, and orientin), one 3-benzoxepine lactone (1,4-methano-3-benzo[d]oxepin-2(1H)-one), one pyridine-4,5-diol derivative (3(2', 3'-dihydroxy-4'-hydroxymethyltetrahydrofuran-1'-yl) pyridine-4,5-diol), six megastigmanes, and megastigmane glycosides (sedumoside $\mathrm{F}_{1},(3 S, 5 R, 6 \mathrm{~S}, 9 R)-3,6$-dihydroxy-5,6dihydro- $\beta$-ionol, 4,5-dihydroblumenol A, ampelopsisionoside, simplicifloranoside, and $(6 S, 9 R)$-roseoside) [39]. The methods used for structure elucidation were high-resolution electrospray ionization (HR-ESI)-MS, and one-dimensional (1D) and two-dimensional NMR (2D-NMR) spectroscopy [39].

\section{Volatile Compounds}

Researchers have studied the volatile organic compounds present in the leaves of P. erosus through gas chromatography coupled with mass spectroscopy and have identified 21 volatile organic compounds present in the leaves (Table S1 Supplementary Materials). P. erosus has more volatile compounds compared to other nearby species, i.e., P. ferrugineus. P. erosus contains mainly aldehydes, ketones, and alcohols among its volatile organic compounds [40].

In a recent study, several important bioactive compounds from the leaves of P. erosus, including gentisic acid, p-hydroxybenzoic acid, p-coumaric acid, salicylic acid, L-phenylalanine, and malonyl daidzin were identified. The concentrations of the compounds were found to vary with the applied light source [4] which suggests that the optimal concentration of important phytoconstituents can be achieved through artificial light. 
Table 1. Phytochemicals with potential antioxidant properties identified in P. erosus.

\begin{tabular}{|c|c|c|c|c|c|c|}
\hline Sr. & Name & Type & Amount/Yield & Sample & Activity & References \\
\hline 1 & 12a-Hydroxydolineone & Rotenoids & $31 \mu \mathrm{g} / \mathrm{g}$ & Seeds & Against HSV types 1 and 2 & {$[9,10]$} \\
\hline 2 & 12a-Hydroxyerosone & Rotenoids & $6 \mu \mathrm{g} / \mathrm{g}$ & Seeds & NA & [10] \\
\hline 3 & 12a-hydroxypachyrhizone & Rotenoids & $36 \mu \mathrm{g} / \mathrm{g}$ & Seeds & Against HSV types 1 and 2 & {$[9,10,38]$} \\
\hline 4 & 12a-Hydroxyrotenone & Rotenoids & $9 \mu \mathrm{g} / \mathrm{g}$ & Seeds & $\begin{array}{l}\text { Anticancer and against } \\
\text { HSV types } 1 \text { and } 2\end{array}$ & {$[9,10]$} \\
\hline 5 & Dehydroneotenone & Isoflavone & $4 \mu \mathrm{g} / \mathrm{g}$ & Seeds & Antifungal activity & {$[9,10,13]$} \\
\hline 6 & Dolineone & Rotenoids & $60 \mu \mathrm{g} / \mathrm{g}$ & Seeds & Antifungal activity & {$[9,13,38]$} \\
\hline 7 & Erosone & Isoflavonoids & & Seeds & Antifungal activity & [13] \\
\hline 8 & Munduserone & Rotenoids & & Seeds & NA & [10] \\
\hline 9 & Neodulin & $\begin{array}{l}\text { 3-arylcoumarin } \\
\text { (pterocarpan) }\end{array}$ & $3.4 \% \mu \mathrm{g} / \mathrm{g}$ & Seeds & NA & [10] \\
\hline 10 & Neotenone & Isoflavonoids & $41 \mu \mathrm{g} / \mathrm{g}$ & Seeds & NA & [9] \\
\hline 11 & Pachyrrhizine & Isoflavonoids & $35 \mu \mathrm{g} / \mathrm{g}$ & $\begin{array}{l}\text { Seeds } \\
\text { Seeds } \\
\text { Seeds }\end{array}$ & Antifungal activity & $\begin{array}{c}{[9,10,13} \\
38]\end{array}$ \\
\hline 12 & Pachyrrhizone & Rotenoids & $117 \mu \mathrm{g} / \mathrm{g}$ & Seeds & Antifungal activity & {$[9,13]$} \\
\hline 13 & Pachyrrhisomene & Pterocarpan & $04.7 \mu \mathrm{g} / \mathrm{g}$ & Seeds & NA & [10] \\
\hline 14 & Rotenone & Rotenoids & $153 \mu \mathrm{g} / \mathrm{g}$ & Seeds & $\begin{array}{l}\text { Anticancer and antifungal } \\
\text { activity }\end{array}$ & {$[10,13,38]$} \\
\hline 15 & $(8,9)$-Furanyl-pterocarpan-3-ol & Pterocarpan & $141.05 \mu \mathrm{g} / \mathrm{g}$ & Tuber & $\begin{array}{l}\text { Antioxidant and skin } \\
\text { whitening }\end{array}$ & {$[6,37]$} \\
\hline 16 & $\begin{array}{l}\text { 2-Butoxy-2,5-bis(hydroxymethyl)- } \\
\text { tetrahydrofurane-3,4-diol }\end{array}$ & Other & & Tuber & $\begin{array}{l}\text { Antioxidant and skin } \\
\text { whitening }\end{array}$ & [37] \\
\hline 17 & $\begin{array}{l}\text { 4-(2-(Furane-2-yl)ethyl)-2-methyl-2,5- } \\
\text { dihydro-furane-3-carbaldehyde }\end{array}$ & Other & & Tuber & $\begin{array}{l}\text { Antioxidant and skin } \\
\text { whitening }\end{array}$ & [37] \\
\hline 18 & $\begin{array}{l}\text { 5-Hydroxy-daidzein-7-O- } \beta \text { - } \\
\text { glucopyranose }\end{array}$ & Isoflavonoids & & Tuber & Skin whitening & [6] \\
\hline 19 & $\begin{array}{c}\text { Daidzein-7-O- } \beta \text {-glucopyranose } \\
\text { /Daidzin }\end{array}$ & Isoflavonoids & $329.93 \pm 10.00 \mu \mathrm{g} / \mathrm{g}$ & Tuber & $\begin{array}{l}\text { Antioxidant and skin } \\
\text { whitening - }\end{array}$ & {$[4,6,35,37]$} \\
\hline 20 & Genistin & Isoflavonoids & & Tuber & $\begin{array}{l}\text { Antioxidant and skin } \\
\text { whitening }\end{array}$ & [37] \\
\hline 21 & Kaikasaponin III & $\begin{array}{l}\text { Triterpenoid } \\
\text { glycosides } \\
\text { (Saponin) }\end{array}$ & $69 \mu \mathrm{g} / \mathrm{g}$ & Tuber & NA & [35] \\
\hline 22 & Daidzein & Isoflavonoids & $2356.10 \pm 38.47 \mu \mathrm{g} / \mathrm{g}$ & $\begin{array}{l}\text { Tuber } \\
\text { juice }\end{array}$ & $\begin{array}{l}\text { Antioxidant and skin } \\
\text { whitening }\end{array}$ & {$[4,6,37,41]$} \\
\hline 23 & Genistein & Isoflavonoids & $1655.30 \mu \mathrm{g} / \mathrm{g}$ & $\begin{array}{l}\text { Tuber } \\
\text { juice }\end{array}$ & NA & [41] \\
\hline 24 & Formononetin & 7-hydroisoflavones & $65.13 \pm 3.01 \mu \mathrm{g} / \mathrm{g}$ & Leaves & NA & [4] \\
\hline 25 & Gentisic acid & $\begin{array}{l}\text { Dihydroxybenzoic } \\
\text { acid }\end{array}$ & $69.03 \pm 1.00 \mu \mathrm{g} / \mathrm{g}$ & Leaves & NA & [4] \\
\hline 26 & 1-Phenylalanine & Amino acid & $16,654.43 \pm 43.52 \mu \mathrm{g} / \mathrm{g}$ & Leaves & NA & [4] \\
\hline 27 & Malonyl genistin & Glycosyloxyisoflavone & $683.77 \pm 12.69 \mu \mathrm{g} / \mathrm{g}$ & Leaves & NA & [4] \\
\hline 28 & Malonyldaidzin & Glycosyloxyisoflavone & $9853.90 \pm 44.28 \mu \mathrm{g} / \mathrm{g}$ & Leaves & NA & [4] \\
\hline 29 & $p$-Coumaric acid & Aromatic acid & $612.83 \pm 2.02 \mu \mathrm{g} / \mathrm{g}$ & Leaves & NA & [4] \\
\hline 30 & $\begin{array}{l}p \text {-Hydroxybenzoic } \\
\text { acid }\end{array}$ & Aromatic acid & $161.63 \pm 1.52 \mu \mathrm{g} / \mathrm{g}$ & Leaves & NA & [4] \\
\hline 31 & Salicylic acid & Aromatic acid & $58.83 \pm 2.57 \mu \mathrm{g} / \mathrm{g}$ & Leaves & NA & [4] \\
\hline 32 & Vitexin & Flavones & $1970.12 \pm 9.22 \mu \mathrm{g} / \mathrm{g}$ & Leaves & NA & [4] \\
\hline 33 & Isobavachalcone & Flavonoids & $34.3 \mu \mathrm{g} / \mathrm{g}$ & Leaves & Anticancer & [39] \\
\hline 34 & Wighteone & Flavonoids & $2.9 \mu \mathrm{g} / \mathrm{g}$ & Leaves & Anticancer & [39] \\
\hline 35 & Prunin & Flavonoids & $2.7 \mu \mathrm{g} / \mathrm{g}$ & Leaves & NA & [39] \\
\hline 36 & Orientin & Flavonoids & $50 \mu \mathrm{g} / \mathrm{g}$ & Leaves & NA & [39] \\
\hline 37 & Erosusone & Flavonoids & $2 \mu \mathrm{g} / \mathrm{g}$ & Leaves & Anticancer & [39] \\
\hline 38 & 3-episedumoside $\mathrm{F}_{1}$ & $\begin{array}{l}\text { Megastigmane } \\
\text { glycoside epimer }\end{array}$ & $20 \mu \mathrm{g} / \mathrm{g}$ & Leaves & NA & [39] \\
\hline
\end{tabular}




\section{Bioactivities (In Vitro and In Vivo)}

Researchers have isolated and identified different phytochemicals, mainly from the seeds, tubers, and leaves. An indication of the pharmacological activities of P. erosus was known from ancient times and has been reported in the literature, which has been further explored in research performed mostly in the last two decades. The biological activities against different diseases, and its other pharmacological properties, makes P. erosus a probable candidate for further development (Figure 2). This systematic review highlights the different activities and possible directions to pursue further in relation to research on the development of therapeutics. The associated gaps and challenges are discussed in this section. Different parts of the plant have been used for bioactivities in several in vitro, in vivo, ex vivo, and human studies. Different types of extract mediums, forms, and phytochemicals of the plant have been analyzed in studies that are presented in the Sections 6.1-6.12 (Figure 2).

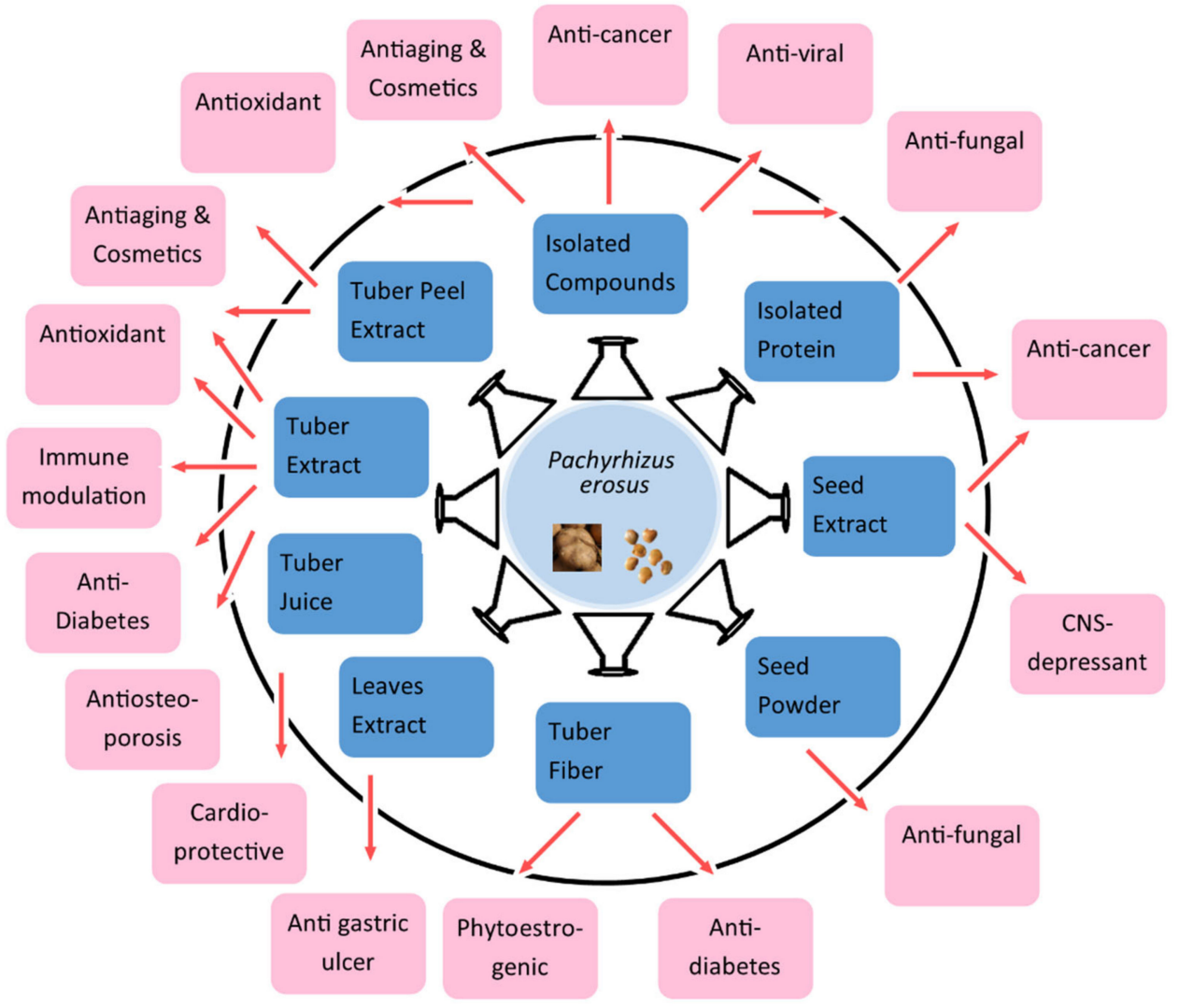

Figure 2. Different biological activities of P. erosus through different extracts and forms reported in literature.

\subsection{Antioxidant and Antiaging Properties}

Antioxidants are an important property which can be responsible for a range of positive outcomes in different diseases and conditions, such as cancer, asthma, diabetes, antiaging treatments, immune modulation, and cosmetics [42-47]. The antioxidant properties of P. erosus compounds isolated from the peel and tuber extracts were reported through various solvents in different studies. The antioxidant properties of an ethyl acetate extract from the tuber of P. erosus (PTE) were assayed by measuring the scavenging activity against 1,1diphenyl-1-picrylhydrazine (DPPH), which is a method to assess the antioxidant potential of samples. The four compounds (daidzein, daidzein-7-O- $\beta$-glucopyranose, 5 -hydroxydaidzein-7-O- $\beta$-glucopyranose, and 8,9-furanyl-pterocarpan-3-ol) isolated from the PTE extract were also studied for their antioxidant properties against DPPH and were found to be active $[6,16]$. In another study, a tyrosinase inhibition assay was also carried out on the extract, as well as other isolated compounds, which is the method to indicate the 
skin whitening property of compounds. The extract, as well as the compounds, had the potential activities needed to justify their use in cosmetics for skin whitening and anti-aging properties [6]. Later, researchers also carried out the antioxidant activities of water and alcohol PTE through DPPH and ABTS (2,2'-azinobis-(3-ethylbenzthiazolin-6-sulfonic Acid)) assay methods, which confirmed the extract's potential as a cosmetic material that possesses anti-oxidant and anti-melanogenic activities [5]. Recently, a 70\% ethanolic P. erosus tuber peel extract (PPE) and PTE were tested for antioxidant properties in a DPPH assay, as well as for skin whitening activities in a tyrosinase inhibition assay, which again confirmed the anti-aging and skin whitening properties of P. erosus. [7].

A limited study has been carried out to decipher the antioxidant mechanisms of the extracts / compounds from P. erosus in organisms. Recently, the treatment of a synbiotic drink made from $P$. erosus juice and kefir grains on Wistar rats (Rattus norvegicus) was studied for oxidative stress markers in the testicular tissue damage caused by hyperlipidemia. The study revealed that the oxidative stress marker malondialdehyde (MDA) was decreased and superoxide dismutase (SOD) was increased in the treatment group. An increase in SOD activity could be a possible mechanism of the antioxidant effects, but this study did not focus precisely on P. erosus and other factors, such as probiotics, were present in the study.

However, earlier studies on the antioxidant compounds found in P. erosus can provide insight into the potential antioxidant mechanisms that may be effective in the in vivo condition. The polyphenolic compounds (such as daidzein) can increase the expression of the proteins, mRNAs, and activities of SOD, which is an important antioxidant target which converts superoxide radicals into ordinary oxygen and hydrogen peroxide [48]. Similarly, vitexin is found to exert its antioxidant effects through the reduction in the level of reactive oxygen species (ROS) and MDA inside the cells, which is attributed to the increase in the activity of antioxidant enzymes like SOD, glutathione, heme oxygenase, and NAD(P)H quinone oxidoreductase 1 . It also upregulates the antioxidant response proteins, such as AMP-activated protein kinases and nuclear factor erythroid 2-related factor 2 [49-52]. Metal chelation through the polyphenolic compound of $P$. erosus can also be an important mechanism for antioxidant activity. Polyphenols can chelate metal at physiological $\mathrm{pH}$ values. Hence, most polyphenols are effective metal chelators in the biological system [53]. The polyphenols reported from $P$. erosus can decrease the production of hydroxyl radicals in the Fenton reaction through the chelation of metal ions such as $\mathrm{Fe}^{2+}$, which is the required substrate in the reaction [54].

Importantly, the antioxidant activity of P. erosus may be one of the important reasons for most of its biological properties, such as its anti-diabetes, anticancer, immune modulating, and gastric ulcer preventions reported from the extracts/compounds of P. erosus [42-46].

\subsection{Anti-Diabetes}

In 2017, it was estimated that more than 450 million adults had diabetes, and the figure is expected to increase without effective control measures [55]. Different approaches have been used to manage this global disease [56-58]. Phytochemicals with pharmacological properties have gained momentum against diabetes in the recent past [59]. The antidiabetes activities of the tuber and seeds in different extracts and forms from $P$. erosus have been studied in different experiments. Researchers have identified the $\alpha$-glucosidase and $\alpha$-amylase inhibitory activities of the tuber extract (PTE) in in vitro assays (Table 2). In vivo studies on male ICR mice showed the normalization effect of the postprandial glucose response in normal, as well as diabetic, mice (Table 3) [60]. In a different study on male $\mathrm{C} 57 \mathrm{BL} / \mathrm{KsJ}-\mathrm{db} / \mathrm{db}$ mice, the administration of aqueous PTE found potential anti-diabetes effects on different parameters such as hemoglobin $\mathrm{A} 1 \mathrm{c}(\mathrm{HbA} 1 \mathrm{c})$, and plasma insulin values were found to be significantly reduced. The hepatic glycogen concentration was found to be increased and the intraperitoneal glucose tolerance test was also found to be improved [61]. A study on male Bagg and Albino (BALB/c) mice with a treatment of tuber fibers resulted in a significant reduction in blood glucose levels [62]. In a recent study, the pancreatic tissue was also found to be protected from high fat diet-induced islet hyperplasia and 
hypertrophy in BALB mice treated with tuber powder $[63,64]$. Probiotic yogurt made from the P. erosus tuber was also found to be effective in decreasing blood glucose in DDY strain mice when compared with normal probiotic yogurt [65].

The important factors for anti-diabetes properties can be attributed to the presence of soluble fibers which include inulin [66], as well as other phytochemicals that are present in the tuber. Dietary inulin has also shown anti-diabetes effects in different studies [67,68].

However, directly drinking the tuber juice of P. erosus, which is rich in carbohydrates (such as fructose and glucose) can cause an increase in blood sugar just after the administration [69].

\subsection{Anticancer}

Cancer is still one of the leading causes of death globally and new cases of cancer patients increased from approximately 18 million in 2018 to potentially more than 23 million new cases per year in 2030 [70]. Synthetic drugs can have major disadvantages, which include drug resistance, side effects, toxicity to normal tissues, and the recurrence of cancer. Phytochemicals are a promising option, as they may have fewer side effects, and there is evidence that phytochemicals can target a wide variety of pathways/signaling pathways in growth, proliferation, differentiation, cell cycles, and apoptosis [71-76].

The anticancer properties of seeds from P. erosus were primarily studied due to the presence of rotenone and similar phytochemicals which were known to have anticancer effects [77]. Recently, the protein present in the seeds was also found to be a highly potent anticancer agent [11].

The anticancer activities of compounds isolated from the seeds were studied in different cancer cell lines. Rotenone and hydroxy-rotenone isolated from the seeds were found to exhibit potent cytotoxic effects on a number of tumor cell lines, such as P-388 in lymphocytic leukemia, $\mathrm{KB}$ in carcinoma of the nasopharynx, a multidrug-resistant variant of $\mathrm{KB}$, $\mathrm{KB}-\mathrm{V} 1$, and a number of human cancer cell lines derived from a variety of tumor types, namely, fibrosarcoma, lung cancer, colon cancer, melanomas, and breast carcinoma $[10,78]$. Significant cytotoxic activity was observed from rotenone isolated from P. erosus seeds on K562 human leukemia cells in MTT assays [38]. Although the toxicity of rotenone and other similar compounds on normal cells can be the major bottleneck in the development of anticancer drugs, recently the radiolytic derivative of rotenone (rotenoisin A) was developed which was safe to use on primary epidermal keratinocytes (no inhibitory effects, as with rotenone) and showed the inhibition of breast cancer cell proliferation, as well as enhanced apoptosis [79]. Similarly, the radiolytic derivative of rotenone (Rotenoisin B) was found to have low toxic effects on normal cells but strong anticancer effects on hepatic cancer through the inhibition of hepatic cancer cell proliferation and an increase in the apoptosis (Table 2) [80].

Researchers have also identified a novel ribosome inactivating protein (pachyerosin) from the seeds of $P$. erosus, which was found to be cytotoxic against the human hepatoma cell line, HuH-7. Furthermore, the immunotoxin prepared from pachyerosin has shown extremely high cytotoxicity in nano-molar concentrations [11]. These results from the different compounds and proteins of the seeds make them attractive candidates against cancer, which can be further pursued in anticancer drug development.

\subsection{Immune Modulation}

Immune modulation is one of the most important properties of P. erosus, which can be utilized to develop it as important intervention against different diseases. Immune modulation can have a positive effect on a number of disease conditions, including cancer and infectious diseases [81-83]. The immune modulatory effects of P. erosus was observed in in vitro, in vivo and ex vivo experiments (Tables 2 and 3).

The P. erosus tuber fiber extract (PTFE) stimulated the production of TNF- $\alpha$ and interlukene-6 (IL-6) through the enhanced gene expression of both the proteins in cells (J774.1 cells) [84]. In the study, an anti-inflammatory cytokine, IL-10, was also found to be increased, which can prevent the damaging effects of macrophages from too much 
activation [85]. Immune-mediated genes, such as iNOS and COX-2, which are expressed in activated macrophages, were also found to be increased in PTFE treated cells in a dosedependent manner, as compared to untreated cells. Similarly, increased levels of TNF- $\alpha$ and interlukene-6 (IL-6) were found in ex vivo and in vivo experiments with peritoneal macrophage (P-Mac) cells and BALB/c mice, respectively [84]. In a recent study, the fiber extract fractions (FEF) were studied for immunomodulatory effects on mouse peritoneal macrophages, lymphocytes, and cytokines. The immune-enhancing effect was observed with FEF treatment with increased phagocytic activity and a stimulation of both TNF- $\alpha$ and IL-6 production [12].

In another study, the IgM production by HB4C5 cells was found to be increased with the application of PTFE in a dose-dependent manner. Furthermore, the in vitro production of IgM, IgG, and IgA was studied in primary splenocytes from the BALB/c mice and was found to increase in a dose-dependent manner (Table 2). In the in vivo study, the oral application of PTFE resulted in increased serum immunoglobin levels and an enhanced production of immunoglobulin and cytokines from the lymphocytes of the spleen, Peyer's patches, and the mesenteric lymph nodes in BALB/c mice [86].

In a recent study, the oral administration of methanolic extracts and ethyl ether fraction from the tuber of $P$. erosus was found to enhance the innate immunity and IgG production in mice already immunized with the Hepatitis B vaccine (HBV) [17]. In a similar study, the in vivo immune modulation activity of water soluble PTF from P. erosus was observed in BALB/c mice. An increase in phagocytotic macrophages, TNF-alpha production, NO production from the peritoneal macrophages, and lymphocyte proliferation was found with the administration of PTFE after the HBV [15] (Tables 2 and 3).

\subsection{Anti Herpes Simplex Virus (HSV)}

Plants and their preparations have been used in folk medicine for antiviral treatments [87]. Some of these natural preparations have been found to target virus replication for antivirus activity [88,89]. Phytochemicals are supposed to have antiviral properties against different viral diseases, with superior pharmacokinetics and low side effects, and are considered a potential intervention against current and emerging viral diseases, including SARS-CoV-2 [90-92]. To evaluate antiviral properties, the researchers isolated nine compounds from the different chemical classes, such as iso-flavonoids, monosaccharides, and rotenoids from the seeds of P. erosus (Table 2). Two compounds (12a-hydroxydolineone and 12a-hydroxypachyrrhizone) belonging to the rotenoids class were found to have anti-herpes simplex virus activity in a plaque reduction assay [9].

\subsection{Antifungal Activity}

Fungi are eukaryotic organisms, so the development of antifungal drugs is more complicated as compared to antibacterial drugs. Therefore, fewer antifungal drugs have been discovered and are available against fungi compared to bacteria. Further drug resistance against antifungal drugs worsens the current scenario for the treatment of fungal diseases and phytochemicals are still the main resource of new antifungal drugs [93]. The antifungal activities were identified from the powder and extracts of the seeds from P. erosus in different studies. The isolated secondary metabolites from the extracts with antifungal properties were then characterized. The antifungal properties were carried out through mycelial inhibition bioassays on three important fungi, named Colletotrichum gloeosporioides, Fusarium oxysporum, and Rhizopus stolonifera (Table 2). The maximum fungicidal effects were attained with rotenone on $R$. stolonifer, with pachyrrizine on F. oxysporum, and with dehydroneotenone on C. gloeosporioides [13]. Further studies are required to develop these compounds (rotenone, dehydroneotenone, and pachyrrizine) as potential drug candidates against fungal diseases. Antifungal proteins were also reported from the seeds of P. erosus, which included PaAFP and the dimeric plant defensin protein SPE10 [94-96]. 
Table 2. Different biological activity through in vitro studies.

\begin{tabular}{|c|c|c|c|c|c|c|}
\hline Sr. No. & Activity & Model/Method & Dose/Duration & Component Used & Result & Reference \\
\hline \multirow{8}{*}{1} & \multirow{8}{*}{$\begin{array}{l}\text { Antioxidant/ } \\
\text { anti-aging }\end{array}$} & DPPH antioxidant assay & $\begin{array}{l}6.25-200 \\
(\mu \mathrm{g} / \mathrm{mL})\end{array}$ & $\begin{array}{c}\text { P. erosus peel } \\
\text { ethanolic extract }\end{array}$ & $\begin{array}{c}\mathrm{IC}_{50}=84.09 \pm 4.87 \\
(\mu \mathrm{g} / \mathrm{mL})\end{array}$ & [7] \\
\hline & & DPPH antioxidant assay & $\begin{array}{l}6.25-200 \\
(\mu \mathrm{m} / \mathrm{mL})\end{array}$ & $\begin{array}{l}\text { P. erosus tuber } \\
\text { ethanolic extract }\end{array}$ & $\begin{array}{c}\mathrm{IC}_{50}=98.30 \pm 1.30 \\
(\mu \mathrm{m} / \mathrm{mL})\end{array}$ & [7] \\
\hline & & Tyrosinase activity inhibition & $\begin{array}{l}3.13-100 \\
(\mu \mathrm{g} / \mathrm{mL})\end{array}$ & $\begin{array}{l}\text { P. erosus peel } \\
\text { ethonolic extract }\end{array}$ & $\begin{aligned} & \mathrm{IC}_{50}=194.51 \pm 7.63 \\
&(\mu \mathrm{m} / \mathrm{mL})\end{aligned}$ & [7] \\
\hline & & Tyrosinase activity inhibition & $\begin{array}{l}3.13-100 \\
(\mu \mathrm{g} / \mathrm{mL})\end{array}$ & $\begin{array}{l}\text { P. erosus tuber } \\
\text { ethonolic extract }\end{array}$ & $\begin{array}{c}\mathrm{IC}_{50}=97.05 \pm 0.86 \\
(\mathrm{gm} / \mathrm{mL})\end{array}$ & [7] \\
\hline & & $\begin{array}{l}\text { Scavenging activity on ABTS } \\
\text { radical }\left(\mathrm{IC}_{50}\right)\end{array}$ & $\begin{array}{c}100 \mu \mathrm{L} \text { at } \\
\text { different } \\
\text { concentrations }\end{array}$ & $\begin{array}{l}\text { P. erosus water } \\
\text { extract }\end{array}$ & $\begin{aligned} \mathrm{IC}_{50}= & 1825.16 \pm 22.87 \\
& (\mu \mathrm{g} / \mathrm{mL})\end{aligned}$ & [5] \\
\hline & & $\begin{array}{l}\text { Scavenging activity on ABTS } \\
\text { radical }\left(\mathrm{IC}_{50}\right)\end{array}$ & $\begin{array}{c}100 \mu \mathrm{L} \text { at } \\
\text { different } \\
\text { concentrations }\end{array}$ & $\begin{array}{l}\text { P. erosus }(70 \%) \\
\text { ethanol extract }\end{array}$ & $\begin{aligned} \mathrm{IC}_{50}= & 1711.71 \pm 58.09 \\
& (\mu \mathrm{g} / \mathrm{mL})\end{aligned}$ & [5] \\
\hline & & DPPH antioxidant assay & $\begin{array}{c}100 \mu \mathrm{L} \text { at } \\
\text { different } \\
\text { concentrations }\end{array}$ & $\begin{array}{l}\text { P. erosus water } \\
\text { extract }\end{array}$ & $\begin{array}{c}\mathrm{IC}_{50}= \\
\underset{(\mu \mathrm{gm} / \mathrm{mL})}{1215.65 \pm} 65.99\end{array}$ & [5] \\
\hline & & DPPH antioxidant assay & $\begin{array}{c}100 \mu \mathrm{L} \text { at } \\
\text { different } \\
\text { concentrations }\end{array}$ & $\begin{array}{l}\text { P. erosus }(70 \%) \\
\text { ethanol extract }\end{array}$ & $\begin{array}{l}\mathrm{IC}_{50}=998.10 \pm \\
117.71(\mu \mathrm{g} / \mathrm{mL})\end{array}$ & [5] \\
\hline \multirow{2}{*}{2} & \multirow{2}{*}{ Anti-diabetes } & $\alpha$-glucosidase inhibitory assay & $\begin{array}{l}0.05-0.25 \\
(\mu \mathrm{g} / \mathrm{mL})\end{array}$ & $\begin{array}{l}\text { P. erosus tuber } \\
\text { extract }\end{array}$ & $\begin{aligned} \mathrm{IC}_{50} & =0.083 \pm 0.004 \\
(\mathrm{mg} / \mathrm{mL}) & 0\end{aligned}$ & {$[60]$} \\
\hline & & $\alpha$-amylase inhibitory activity & $\begin{array}{l}0.05-0.25 \\
(\mu \mathrm{g} / \mathrm{mL})\end{array}$ & $\begin{array}{l}\text { P. erosus tuber } \\
\text { extract }\end{array}$ & $\begin{array}{c}\mathrm{IC}_{50}=0.091 \pm 0.017 \\
(\mathrm{mg} / \mathrm{mL})\end{array}$ & {$[60]$} \\
\hline \multirow{2}{*}{3} & \multirow{2}{*}{$\begin{array}{l}\text { Immune } \\
\text { modulation }\end{array}$} & $\begin{array}{l}\text { ELISA is used to measure } \\
\text { antibodies on HB4C5 cells and } \\
\text { splenocytes }\end{array}$ & $\begin{array}{c}\text { Sample conc. } \\
0.1-100 \\
(\mathrm{mg} / \mathrm{mL})\end{array}$ & $\begin{array}{l}\text { P. erosus tuber } \\
\text { fiber extract }\end{array}$ & $\begin{array}{l}\text { The production levels of } \\
\text { immunoglobulin, i.e., IgM, } \\
\text { IgG, and IgA, as well as } \\
\text { cytokines, were } \\
\text { significantly enhanced }\end{array}$ & [86] \\
\hline & & $\begin{array}{c}\text { Phagocytosis activity J774.1 } \\
\text { cell/P-Mac cells }\end{array}$ & $\begin{array}{l}\text { 1.69, 6.75, and } \\
27 \mathrm{mg} / \mathrm{mL}\end{array}$ & $\begin{array}{l}\text { P. erosus tuber } \\
\text { fiber extract }\end{array}$ & $\begin{array}{c}\text { An increase in } \\
\text { phagocytosis activity and } \\
\text { the production of } \\
\text { pro-inflammatory } \\
\text { cytokines was observed }\end{array}$ & {$[84]$} \\
\hline 4 & Antiviral & $\begin{array}{c}\text { Plaque reduction assay was } \\
\text { performed for } \\
\text { HSV-1 (KOS) or HSV-2 }\end{array}$ & $\begin{array}{l}100 \mu \mathrm{L} \text { at } \\
\text { different } \\
\text { concentrations }\end{array}$ & $\begin{array}{l}\text { Compounds } \\
\text { isolated from } \\
\text { seeds }\end{array}$ & $\begin{array}{l}\text { 12a-hydroxydolineone and } \\
\text { 12a-hydroxypachyrrhizone } \\
\text { found to have activity } \\
\text { against both HSV-1 and -2 }\end{array}$ & [9] \\
\hline \multirow{5}{*}{5} & \multirow{5}{*}{ Antifungal } & $\begin{array}{l}\text { Growth inhibitory effects } \\
\text { on fungi }\end{array}$ & $\begin{array}{l}0.5,2.0,5.0, \text { and } \\
10 \mathrm{mg} / \mathrm{mL}\end{array}$ & $\begin{array}{l}\text { P. erosus seed } \\
\text { powder }\end{array}$ & -2 to $-15 \%$ (inhibition) & [13] \\
\hline & & $\begin{array}{l}\text { Growth inhibitory effects } \\
\text { on fungi }\end{array}$ & $\begin{array}{l}2.0,5.0 \text { and } \\
10 \mathrm{mg} / \mathrm{mL}\end{array}$ & $\begin{array}{l}\text { P. erosus seed } \\
\text { extract with } \\
\text { hexane, } \\
\text { dicloromethane, } \\
\text { and acetone }\end{array}$ & 5.4 to $-64.9 \%$ (inhibition) & [13] \\
\hline & & $\begin{array}{l}\text { Growth inhibitory effects } \\
\text { on fungi }\end{array}$ & $250 \mu \mathrm{g} / \mathrm{mL}$ & $\begin{array}{l}\text { Compounds } \\
\text { isolated from } \\
\text { seeds }\end{array}$ & $2.81-56.2 \%$ (inhibition) & [13] \\
\hline & & $\begin{array}{l}\text { Inhibitory activities on the } \\
\text { growth of different fungi were } \\
\text { determined by } \\
\text { microspectrophotometry }\end{array}$ & $15 \mu \mathrm{g} / \mathrm{ml}$ & $\begin{array}{l}\text { SPE10 (a dimeric } \\
\text { plant defensin } \\
\text { protein) from the } \\
\text { seeds of P. erosus }\end{array}$ & $\begin{array}{c}\mathrm{IC}_{50} \text { of } 15 \mu \mathrm{g} / \mathrm{mL} \\
\text { (most effective against } \\
\text { Bipolaris maydis) }\end{array}$ & [95] \\
\hline & & $\begin{array}{l}\text { Inhibitory activities on the } \\
\text { growth of fungi (Trichoderma } \\
\text { viride and Chrysosporium luteum) }\end{array}$ & $6.2-12.5 \mu \mathrm{g}$ & $\begin{array}{l}\text { PaAFP (the } \\
\text { protein isolated } \\
\text { and purified from } \\
\text { the P. erosus seeds }\end{array}$ & $\begin{array}{l}\text { Trichoderma viride and } \\
\text { Chrysosporium luteum at } \\
6.2 \mu \mathrm{g} \text { and } 12.5 \mu \mathrm{g} \text { per disc, } \\
\text { respectively, } \\
\text { inhibited growth }\end{array}$ & [94] \\
\hline \multirow{2}{*}{6} & \multirow{2}{*}{ Anticancer } & $\begin{array}{c}\text { Human hepatoma cell } \\
\text { line HuH-7 }\end{array}$ & $0.06 \mathrm{~mL} /$ well & $\begin{array}{l}\text { Pachyerosin } \\
\text { protein isolated } \\
\text { from seeds of } \\
\text { P. erosus }\end{array}$ & $\begin{array}{c}\mathrm{IC}_{50} \text { of } 0.050 \pm 0.004 \mathrm{nM} \text { for } \\
\text { pachyerosin(immunotoxin) } \\
\text { and } \mathrm{IC}_{50} \text { of } \\
117.92 \pm 10.21 \mathrm{nM} \text { for } \\
\text { pachyerosin }\end{array}$ & [11] \\
\hline & & $\begin{array}{l}\text { The viability of K562 cells } \\
\text { determined by the MTT assay }\end{array}$ & $0.06 \mathrm{~mL} /$ well & $\begin{array}{l}\text { P. erosus seed } \\
\text { extract (acetone) } \\
\text { and compound } \\
\text { rotenone from } \\
\text { seed extract }\end{array}$ & $\begin{array}{l}\text { The } P \text {. erosus extract and } \\
\text { rotenone displayed } \\
\mathrm{IC}_{50} 40.5 \mathrm{mg} / \mathrm{mL} \text { and } \\
13.05 \mathrm{mM} \text {, respectively }\end{array}$ & [38] \\
\hline
\end{tabular}




\subsection{Phytoestrogenic Potential}

Phytoestrogens are potential candidates for the prevention of cardiovascular diseases and postmenopausal osteoporosis [97,98]. Tuber juice from P. erosus was found to have estrogenic potential in different studies on animals $[14,41,99,100]$. The estrogenic activity may be due to the compounds present in the tuber juice, such as genistein and daidzein, that structurally resemble estrogen. The rats treated with P. erosus juice for 24 days had significant myometrium proliferation compared to the non-treated group [41]. Similar experiments in mice treated with P. erosus tubers for 24 days resulted in the proliferation of both secondary and tertiary uterine follicles [99]. In a recent study, rats treated with depo-medroxyprogesterone acetate (DMPA), which causes a hypoestrogenic response, were orally administered an ethanol extract of tubers (ETE). The significant increase in the number of antral follicles and endometrial stromal follicles were observed in the ETE treated groups (Table 3). The treated rats also showed an increased amount of endometrial epithelium in the study [100]. In these studies, it was suggested that the natural estrogenic role of $P$. erosus can be further developed to fulfill the need for estrogen therapies for premenopausal and postmenopausal women.

\subsection{Anti-Osteoporosis Potential}

Ovariectomized rat models of osteoporosis were used to explore the anti-osteoporosis effects of the ethyl acetate extract of the P. erosus tuber (PTE). An increase in bone density and mineral content, such as calcium and phosphorus in bone ash, was observed in the PTE administered group (Table 3). An increase in the bone length of the femur and tibiae were also reported in the treatment group and the ultimate load and stiffness of the femur was also significantly increased in the mechanical tests [14]. Researchers proposed that the phytoestrogenic compounds present in the PTE might be responsible for the activity and they suggested the potential of PTE medicinal extracts against osteoporosis in postmenopausal women.

\subsection{The Promotion of Cardiovascular Health}

Cardiovascular diseases are the most important concern for human health and are responsible for the highest mortality in the world [101]. The cardiovascular health-promoting effects of P. erosus tuber juice (PTJ) was studied in healthy volunteers for its effects on their heart rate, systolic and diastolic blood pressure, serum $\mathrm{K}^{+}$concentrations, ex vivo platelet aggregation, and plasma cGMP concentrations. PTJ attenuated ex vivo collageninduced platelet aggregation and also reduced the diastolic blood pressure in the healthy volunteers (Table 3) [102]. Dietary nitrates present in PTJ can be absorbed after ingestion, converted to nitrite, and further converted to $\mathrm{NO}$, which may attenuate platelet responses to collagen stimulation.

In the recent preliminary research on hyperlipidemic rats treated with the synbiotic drink from PTJ concentrate, the MDA level in the heart tissue of the rats improved. The study suggests the potential role of PTJ in lowering the risk of hypertension [103]. Further research is required to understand the molecular mechanisms and to develop PTJ as a therapeutic candidate or prophylactic intervention for cardiovascular health.

\subsection{Central Nervous System Depressant Activity}

Central nervous system depressants (CNSDs) are an important class of drugs. Phytochemicals that, as natural compounds, may possess superior properties for blood-brain barrier penetration which makes them better candidates for CNSDs [104]. The researchers explored the CNSD activity of seeds from P. erosus, as in folk medicine these seeds were used to treat insomnia. The ethanolic extract of seeds was used in mice to test locomotor activity, muscle coordination, behaviors, sleep, and anxiety (Table 3). The results from study revealed that the seed extract produced muscle relaxation effects, reduced locomotor activity, and increased antianxiety and anti-aggressive activities [8]. In different experi- 
ments, CNSD activity was observed; however, more detailed studies are required to explore the potential of P. erosus for CNSD activity.

\subsection{Preventive Effects in Gastric Ulcers}

Considering the antioxidant effects of P. erosus, the juice of the tuber has been evaluated as a preventive agent on alcohol-induced gastric ulcers in mice [105]. A high consumption of alcohol is known to impair the gastric mucosal barrier, causing extensive hemorrhagic injuries, an accumulation of oxidative stress, and increased inflammation [106]. Different doses of juice from P. erosus and Raphanus sativus separately and in combination were given to mice in the experiments. Tuber juice from P. erosus was found to be the most effective in the prevention of gastric ulcers in histopathology and in index values of gastric ulcers [105].

\subsection{Insecticidal Activity}

The insecticidal activity of extracts from the seeds and leaves of P. erosus was studied against different insects $[107,108]$. The long-term oviposition deterrent activity of the seed extract was observed in the diamondback moth (Plutella xylostella) on its plant host, which was maintained for a long time due to the low volatility of the extract [108]. In another study, water and ethanolic extracts of seeds of P. erosus had the highest (compared to two other plants, i.e., Hyptis suaveolens and Apium graveolens) insecticidal activity against the larvae and adults of Aedes aegypti, which is the dengue virus vector [109]. Similarly, insecticidal activity against odorous house ants (Tapinoma sessile) was found to be better than arrowhead (Syngonium podophyllum) (Table 3). Researchers found the insecticidal activity of extracts from $P$. erosus highly promising, and also proposed the need to further extend the investigation of insecticidal activity against other important insects [107,108].

Table 3. Different biological activities of P. erosus through in vivo, ex vivo, and human studies.

\begin{tabular}{|c|c|c|c|c|c|c|}
\hline Sr. No. & Activity & Model & Dose Duration & Substance & Result & References \\
\hline \multirow{6}{*}{1} & \multirow{6}{*}{ Anti-diabetes } & $\begin{array}{l}\text { Male ICR mice induced } \\
\text { for diabetes mellitus by } \\
\text { streptozotocin } \\
\text { Blood glucose was } \\
\text { measured using a } \\
\text { glucometer }\end{array}$ & $\begin{array}{l}(200 \mathrm{mg} / \mathrm{kg}) \text { at } 0 \\
30,60, \text { and } \\
120 \mathrm{~min}\end{array}$ & $\begin{array}{l}\text { P. erosus tuber } \\
\text { extract }\end{array}$ & $\begin{array}{l}\text { The AUC for the glucose response of } \\
\text { P. erosus extract-fed group } \\
(658.1 \pm 18.0 \mathrm{mg} \cdot \mathrm{h} / \mathrm{dL}) \text { was lower } \\
\text { than that of the control group } \\
(742.5 \pm 24.7 \mathrm{mg} \cdot \mathrm{h} / \mathrm{dL})(p<0.05)\end{array}$ & {$[60]$} \\
\hline & & $\begin{array}{c}\text { Male C57BL/KsJ-db/db } \\
\text { mice; blood glucose and } \\
\text { glycosylated hemoglobin } \\
\text { levels }\end{array}$ & $\begin{array}{l}(0.5 \mathrm{~g} / 100 \mathrm{~g} \text { diet }) \\
6 \text { weeks }\end{array}$ & $\begin{array}{l}\text { P. erosus tuber } \\
\text { extract in water }\end{array}$ & $\begin{array}{l}\text { HbA1c values for } P \text {. erosus } \\
\text { extract-fed group }(9.11 \pm 1.06) \text { was } \\
\text { lower than that of the control group } \\
(12.92 \pm 0.31) \text { in } \mathrm{db} / \mathrm{db} \text { control } \\
\text { groups }(p<0.05)\end{array}$ & {$[61]$} \\
\hline & & Plasma insulin level & $\begin{array}{c}(0.5 \mathrm{~g} / 100 \mathrm{~g} \text { diet }) \\
6 \text { weeks }\end{array}$ & $\begin{array}{l}\text { P. erosus tuber } \\
\text { extract in water }\end{array}$ & $\begin{array}{l}\text { Plasma insulin values for } P \text {. erosus } \\
\text { extract-fed group }(191.85 \pm 4.65) \\
\text { was lower than that of the control } \\
\text { group }(251.04 \pm 25.24) \text { in } \\
\text { db/db-control groups }(p<0.05)\end{array}$ & {$[61]$} \\
\hline & & $\begin{array}{l}\text { Homeostatic index of } \\
\text { insulin resistance } \\
\text { (HOMA-IR) and } \\
\text { quantitative insulin } \\
\text { sensitivity check index } \\
\text { (QUICKI) }\end{array}$ & $\begin{array}{c}(0.5 \mathrm{~g} / 100 \mathrm{~g} \text { diet }) \\
6 \text { weeks }\end{array}$ & $\begin{array}{l}\text { P. erosus tuber } \\
\text { extract in water }\end{array}$ & $\begin{array}{l}\text { HOMA-IR values for } P . \text { erosus } \\
\text { extract-fed group }(22.26 \pm 0.53) \text { was } \\
\text { lower than that of the control group } \\
(40.43 \pm 4.03) \text { in } \mathrm{db} / \mathrm{db} \text {-control } \\
\text { groups }(p<0.05) \text {. QUICKI values for } \\
\text { P. erosus extract fed group } \\
(0.24 \pm 0.01) \text { was higher than that of } \\
\text { the control group }(0.22 \pm 0.01) \text { in } \\
\mathrm{db} / \mathrm{db} \text {-control groups }(p<0.05)\end{array}$ & {$[61]$} \\
\hline & & $\begin{array}{l}\text { Intraperitoneal glucose } \\
\text { tolerance test (IPGTT) }\end{array}$ & $\begin{array}{l}(0.5 \mathrm{~g} / 100 \mathrm{~g} \text { diet }) \\
6 \text { weeks }\end{array}$ & $\begin{array}{l}\text { P. erosus tuber } \\
\text { extract in water }\end{array}$ & $\begin{array}{l}\text { IPGTT outcomes were improved in } \\
\mathrm{db} / \mathrm{db} \text {-JCE group mice compared to } \\
\mathrm{db} / \mathrm{db} \text {-control group mice }\end{array}$ & {$[61]$} \\
\hline & & Hepatic glycogen assay & $\begin{array}{l}(0.5 \mathrm{~g} / 100 \mathrm{~g} \text { diet }) \\
6 \text { weeks }\end{array}$ & $\begin{array}{l}\text { P. erosus tuber } \\
\text { extract in water }\end{array}$ & $\begin{array}{l}\text { Hepatic glycogen concentration } \\
\text { values for P. erosus extract-fed group } \\
(116.49 \pm 5.12) \text { were higher than that } \\
\text { of the control group } \\
(90.25 \pm 4.75 \mathrm{mg} / \mathrm{g}) \text { in } \\
\mathrm{db} / \mathrm{db} \text {-control groups }(p<0.05)\end{array}$ & {$[61]$} \\
\hline
\end{tabular}


Table 3. Cont.

\begin{tabular}{|c|c|c|c|c|c|c|}
\hline Sr. No. & Activity & Model & Dose Duration & Substance & Result & References \\
\hline & & $\begin{array}{l}\text { Male Bagg and Albino } \\
\text { (BALB)/c mice fed with } \\
\text { HSD } \\
\text { Blood glucose } \\
\text { measurements }\end{array}$ & $\begin{array}{l}10 \% \text { and } 25 \% \\
\text { P. erosus tuber } \\
\text { Fiber (PTF) in diet } \\
\text { 8over } 8 \text { weeks }\end{array}$ & $\begin{array}{l}\text { P. erosus tuber } \\
\text { fiber }\end{array}$ & $\begin{array}{l}\text { Blood glucose level was significantly } \\
\text { lower in JF groups (HSD + JF } 10 \% \text {, } \\
\text { and HSD + JF } 25 \%) \text { as compared } \\
\text { with HSD group, starting at } 4 \text { th } \\
\text { week of treatment }(p<0.05)\end{array}$ & {$[62]$} \\
\hline & & $\begin{array}{l}\text { Body weight and adipose } \\
\text { tissue measurements }\end{array}$ & $\begin{array}{l}10 \% \text { and } 25 \% \text { PTF } \\
\text { in 8-week diet }\end{array}$ & $\begin{array}{l}\text { P. erosus tuber } \\
\text { fiber }\end{array}$ & $\begin{array}{c}\text { The body weight gain was } \\
\text { significantly lower in JF } 25 \% \text { group, } \\
\text { but not in JF } 10 \% \text { group, as compared } \\
\text { with HSD group }(p<0.01)\end{array}$ & [62] \\
\hline & & 24 male DDY strain mice & $\begin{array}{c}\text { Yogurt, } 2 \mathrm{~mL} \text { for } \\
7 \text { days }\end{array}$ & $\begin{array}{l}\text { Probiotic } \\
\text { treatment group } \\
\text { vs. using } \\
\text { P. erosus, yogurt } \\
\text { and control }\end{array}$ & $\begin{array}{l}\text { P. erosus probiotic yogurt more } \\
\text { effectively decreased } \\
(337.57 \pm 90.01 \mathrm{mg} / \mathrm{dL}) \text { blood } \\
\text { glucose levels than the probiotic } \\
\text { yogurt }(p=0.00)\end{array}$ & [65] \\
\hline & & $\begin{array}{l}\text { BALB (Bagg and } \\
\text { Albino)/c mice }\end{array}$ & $\begin{array}{l}10 \% \text { and } 25 \% \text { with } \\
\text { high-fat diet for } \\
8 \text { weeks }\end{array}$ & $\begin{array}{l}\text { P. erosus tuber } \\
\text { fiber powder }\end{array}$ & $\begin{array}{l}\text { Blood glucose was significantly } \\
\text { lower in the treated groups and } \\
\text { normal group. The pancreatic tissue } \\
\text { was protected from high-fat diet } \\
\text { induced islet hyperplasia and } \\
\text { hypertrophy in mice treated the } \\
\text { treatment group }\end{array}$ & {$[63,64]$} \\
\hline & & $\begin{array}{l}\text { 40-50-year-old people; } 10 \\
\text { people as a case group } \\
\text { and } 10 \text { people as a } \\
\text { control group }\end{array}$ & $\begin{array}{l}\text { Dose of } 250 \mathrm{~g} \\
(150 \mathrm{~mL}) \text { per day } \\
\text { given for } 7 \text { days }\end{array}$ & $\begin{array}{l}\text { P. erosus starch } \\
\text { extract }\end{array}$ & $259.90 \mathrm{mg} / \mathrm{dL}$, then $185.40 \mathrm{mg}$ & [110] \\
\hline & & $\begin{array}{l}\text { Male and female } \\
\text { Wistar strain rats; } \\
\text { hampering blood glucose } \\
\text { in rat models }\end{array}$ & $\begin{array}{l}7 \text { mL juice with } \\
\text { glucose }(50 \% \\
\text { concentration } \\
2.5 \mathrm{gm} / \mathrm{kg})\end{array}$ & $\begin{array}{l}\text { P. erosus tuber } \\
\text { juice }\end{array}$ & $\begin{array}{c}\text { The mean increase of blood glucose } \\
\text { level was } \\
324.45 \mathrm{mg} / \mathrm{dL}\end{array}$ & [69] \\
\hline \multirow{5}{*}{2} & \multirow{5}{*}{$\begin{array}{l}\text { Immune } \\
\text { modulation }\end{array}$} & $\begin{array}{l}\text { Male BALB/c mice } \\
\text { induced with hepatitis } \\
\text { B vaccine }\end{array}$ & $\begin{array}{l}25,50, \text { and } \\
100 \mathrm{mg} / \mathrm{kg} \\
\text { P. erosus tuber fiber } \\
\text { extract for } 18 \text { days }\end{array}$ & $\begin{array}{l}\text { P. erosus tuber } \\
\text { fiber extract }\end{array}$ & $\begin{array}{l}\text { Treatment stimulated phagocytotic } \\
\text { macrophages, NO production from } \\
\text { peritoneal macrophages, and in vivo } \\
\text { lymphocyte proliferation. } \\
\text { Enhancements in phagocytic } \\
\text { capacity index characterized by } \\
\text { increased NO, IL-10, and } \\
\text { TNF-production }\end{array}$ & [15] \\
\hline & & $\begin{array}{l}\text { Male BALB/c mice } \\
\text { induced with hepatitis } \\
\text { B vaccine }\end{array}$ & $\begin{array}{l}100 \text { and } \\
200 \mathrm{mg} / \mathrm{kg} \text { for } \\
18 \text { days }\end{array}$ & $\begin{array}{l}\text { Methanolic and } \\
\text { ethyl ether } \\
\text { fraction (FAEF) } \\
\text { from the tuber } \\
\text { of P. erosus }\end{array}$ & $\begin{array}{l}\text { Enhanced the innate immune } \\
\text { response and IgG production. The } \\
\text { immune enhancing effect was } \\
\text { observed with FAEF treatment with } \\
\text { increased phagocytic activity, and } \\
\text { stimulation of both TNF- } \alpha \text { and } \\
\text { IL-6 production }\end{array}$ & [17] \\
\hline & & Female BALB/c mice & $\begin{array}{l}6.75 \text { or } 27 \mathrm{mg} / \mathrm{kg} \\
\text { body weight for } \\
14 \text { days }\end{array}$ & $\begin{array}{l}\text { P. erosus tuber } \\
\text { fiber extract }\end{array}$ & $\begin{array}{l}\text { BFE may activate the } \\
\text { adaptive immune } \\
\text { responses by enhancing the } \\
\text { production of Igs and cytokines } \\
\text { in vivo }\end{array}$ & [86] \\
\hline & & $\mathrm{BALB} / \mathrm{c}$ mice & $\begin{array}{c}6.75 \mathrm{mg} / \mathrm{kg} \text { and } 27 \\
\mathrm{mg} / \mathrm{kg} \text { for } 7 \text { days }\end{array}$ & $\begin{array}{l}\text { P. erosus tuber } \\
\text { fiber extract }\end{array}$ & $\begin{array}{l}\text { BFE could activate macrophages by } \\
\text { increasing the phagocytosis activity } \\
\text { and production of pro-inflammatory } \\
\text { cytokines in mouse P-Mac in vitro } \\
\text { and in vivo }\end{array}$ & [84] \\
\hline & & BALB/c mice & $\begin{array}{c}6.75 \text { and } \\
27 \mathrm{mg} / \mathrm{mL}\end{array}$ & $\begin{array}{l}\text { Tuber fiber } \\
\text { extract }\end{array}$ & $\begin{array}{c}\text { Phagocytosis activity percentage of } \\
\text { P-Mac ex vivo increased from } \\
32.1 \pm 1.9 \text { to } 42.6 \pm 4.6(p<0.001)\end{array}$ & {$[84]$} \\
\hline \multirow{3}{*}{3} & \multirow{3}{*}{$\begin{array}{l}\text { Phytoesterogenic } \\
\text { activity }\end{array}$} & $\begin{array}{c}\text { Female Sprague-Dawley } \\
\text { rat } \\
\text { histopathology }\end{array}$ & $\begin{array}{l}1.5 \mathrm{~mL} P . \text { erosus } \\
\text { tuber juice for } \\
24 \text { days }\end{array}$ & $\begin{array}{l}\text { P. erosus tuber } \\
\text { juice }\end{array}$ & $\begin{array}{l}\text { The myometrium in rats with } \\
\text { P. erosus tuber juice treatment was } \\
\text { wider than controls and pure } \\
\text { daidzein treatment }\end{array}$ & [41] \\
\hline & & $\mathrm{BALB} / \mathrm{c}$ female & $\begin{array}{l}0.3,0.6, \text { and } \\
0.9 \mathrm{~g} / \mathrm{kg} \text { for } \\
24 \text { days }\end{array}$ & P. erosus tuber & $\begin{array}{c}\text { Treatment caused proliferation of the } \\
\text { uterine endometrium and } \\
\text { myometrium layers and increased } \\
\text { the number of uterine glands }\end{array}$ & [99] \\
\hline & & Rats (Female) & $\begin{array}{l}\text { Three oral doses: } \\
70,140, \text { and } \\
280 \mathrm{mg} / 200 \mathrm{~g} \\
\text { every day for } \\
14 \text { days }\end{array}$ & $\begin{array}{l}\text { Tuber ethanol } \\
\text { extract }\end{array}$ & $\begin{array}{l}\text { Significantly increased the number } \\
\text { of antral follicles and endometrial } \\
\text { stromal follicles; increased the } \\
\text { amount of endometrial epithelium } \\
\text { was observed }\end{array}$ & [100] \\
\hline
\end{tabular}


Table 3. Cont.

\begin{tabular}{|c|c|c|c|c|c|c|}
\hline Sr. No. & Activity & Model & Dose Duration & Substance & Result & References \\
\hline 4 & $\begin{array}{c}\text { Anti- } \\
\text { osteoporosis }\end{array}$ & $\begin{array}{l}\text { Female Sprague-Dawley } \\
\text { rats }\end{array}$ & $\begin{array}{l}200,400, \text { and } \\
800 \mathrm{mg} / \mathrm{kg} \text { for } \\
28 \text { days }\end{array}$ & $\begin{array}{l}\text { Ethyl acetate } \\
\text { extract of } \\
\text { P. erosus tuber }\end{array}$ & $\begin{array}{c}\text { Femoral length, tibiae length, bone } \\
\text { density of bone ash; content of } \\
\text { calcium, and bone ash content of } \\
\text { phosphorus increased to } \\
32.51 \pm 0.92 \mathrm{~mm}, 37.25 \pm 0.57 \mathrm{~mm} \\
1.441 \pm 0.064 \mathrm{~g} / \mathrm{cm}^{3}, 50.02 \pm 6.55 \% \\
\text { and } 32.73 \pm 1.09 \% \text {, respectively }\end{array}$ & [14] \\
\hline 5 & $\begin{array}{l}\text { Cardio } \\
\text { protection }\end{array}$ & $\begin{array}{l}\text { Human platelet } \\
\text { aggregation study and } \\
\text { blood pressure } \\
\text { measurement }\end{array}$ & $500 \mathrm{~mL}$ & $\begin{array}{l}\text { P. erosus tuber } \\
\text { juice }\end{array}$ & $\begin{array}{l}\text { The ex vivo collagen-induced platelet } \\
\text { aggregation was significantly } \\
\text { attenuated, as well as } \\
\text { platelet inhibition and blood } \\
\text { pressure lowering }\end{array}$ & [102] \\
\hline 6 & $\begin{array}{l}\text { Central } \\
\text { nervous system } \\
\text { depressant } \\
\text { activity }\end{array}$ & $\begin{array}{l}\text { Swiss albino mice of } \\
\text { either sex }\end{array}$ & 75 and $150 \mathrm{mg} / \mathrm{kg}$ & $\begin{array}{l}\text { Ethanolic seed } \\
\text { extract of } \\
\text { P. erosus }\end{array}$ & $\begin{array}{l}\text { Ethanolic extract of seeds of } \\
\text { P. erosus possess } \\
\text { sedative, anti-anxiety, muscle } \\
\text { relaxant, and anti-aggressive } \\
\text { properties in different experiments }\end{array}$ & [8] \\
\hline 7 & $\begin{array}{l}\text { Preventive } \\
\text { effects on } \\
\text { gastric ulcers }\end{array}$ & $\begin{array}{c}\text { Swiss } \\
\text { Webster mice }\end{array}$ & $\begin{array}{l}100,300, \text { and } \\
600 \mathrm{mg} / \mathrm{kg}\end{array}$ & $\begin{array}{l}\text { P. erosus tuber } \\
\text { juice }\end{array}$ & $\begin{array}{l}\text { Reduced the number of ulcers, } \\
\text { increased the ratio of protection, and } \\
\text { repaired the cells in gastric } \\
\text { histopathology }\end{array}$ & [105] \\
\hline \multirow[t]{2}{*}{8} & \multirow[t]{2}{*}{$\begin{array}{l}\text { Insecticidal } \\
\text { activity }\end{array}$} & $\begin{array}{l}\text { Insecticide } \\
\text { oviposition deterrent } \\
\text { activity }\end{array}$ & $0.1-2.0(\% W / v)$ & $\begin{array}{l}\text { P. erosus seed } \\
\text { extract in } \\
\text { chloroform }\end{array}$ & $\begin{array}{l}\text { Oviposition deterrent indices } \\
\text { P. erosus seed extracts and coumarin } \\
\text { partially deterred the diamondback } \\
\text { moth adults from laying eggs on } \\
\text { treated leaves in a } \\
\text { concentration-dependent manner }\end{array}$ & [108] \\
\hline & & $\begin{array}{l}\text { Larvae and adults of } \\
\text { Aedes aegypti }\end{array}$ & Up to $100 \mathrm{mg} / \mathrm{mL}$ & $\begin{array}{l}\text { P. erosus seed } \\
\text { water and }(70 \%) \\
\text { alcoholic extract }\end{array}$ & $\begin{array}{c}\text { Lethal concentration } 50\left(\mathrm{LC}_{50}\right) \text { of } \\
16.22 \pm 0.20 \mu \mathrm{g} / \mathrm{mL} \text { and } \mathrm{LC}_{0} \text { value } \\
\text { of } 91.41 \pm 0.49 \mu \mathrm{g} / \mathrm{mL}\end{array}$ & [109] \\
\hline
\end{tabular}

\section{Gaps and Future Directions}

P. erosus has shown positive outcomes for a number of diseases, along with its use as a food crop, which makes this plant highly important, demanding further research and development efforts to establish the medicinal/health supplement properties for possible health-promoting usages. A high nutritional profile with nitrogen-fixing properties and the biodiesel potential of the seed oil are important reasons to increase its production in different countries. This also highlights the requirement to expedite the directional research efforts to develop the pharmacological applications of the plant. However, the different medicinal properties of the plant have different possible challenges.

The antioxidant and immune modulation properties of the P. erosus were found in several studies, which can strongly establish these findings. These properties can be taken as the key prospective biological properties of the plant, as these biological properties have positive effects against several diseases. Immune modulation has been studied in in vivo, in vitro, and ex vivo experiments, but like other known biological properties (such as anticancer, antiviral, and antifungal properties) the compounds responsible for immune modulation are not well known/studied. Additionally, the molecular mechanisms for immune modulation of the P. erosus extracts are also not well studied, which can hinder its development as a therapeutic for immune modulation. Furthermore, a major limitation is the absence of human/clinical studies to establish the immune modulation properties of P. erosus. Clinical trials/studies are, therefore, required and proposed for its development as a therapeutic and/or as a food supplement for immune modulation.

In the case of the antioxidant properties, which have been already utilized for cosmetics in different products [111], as for immune modulation, the compounds for antioxidant activity are not well studied/known. Studies on the responsible compounds and molecular mechanisms of antioxidants must be pursued in the near future for the optimal utilization of antioxidant properties, not only in cosmetics, but also for anti-aging and to treat other important diseases.

The anti-diabetes properties of P. erosus was also apparent in several studies (Tables 2 and 3). The soluble fibers, such as inulin, are one of the main suspected constituents that can be 
considered as the reason for its anti-diabetes properties $[67,68]$. However, anti-diabetes compounds/constituents are not precisely studied from $P$. erosus and are yet to be discovered. The important gap which must be filled for the development of P. erosus as an anti-diabetes intervention are clinical/human studies, which must be carried out as a high priority. Different studies on animals have supported its anti-diabetes potential and the long-term usage of the tuber as food in different countries have abolished the potential risk in clinical/human studies. However, the sudden increase in blood glucose levels with the intake of juice from the tuber is reported; therefore, tuber juice, if used in diabetic subjects, might require special precautions.

The major challenge to develop anticancer drugs from P. erosus is the toxicity of known anticancer compounds used from the seeds of P. erosus, which can be overcome with the discovery of nontoxic constituents important for anticancer activities from P. erosus. Secondly, the researchers have been preparing less toxic/nontoxic derivatives of the toxic constituent rotenone. Anticancer studies of $P$. erosus have been mostly limited to various cell lines, which must be first addressed in in vivo and mechanistic experiments before clinical studies.

The antimicrobial potential against antifungal and antiviral activities were discovered and the compounds of the activities were also identified (Table 2). Antifungal proteins were also identified from the plant [94-96]. The development of P. erosus (powder, extract, or the extracted compound) as an anti-microbial therapy requires further research efforts, which include the study of the antimicrobial potential against other infectious diseases and the safe study of seed extracts and compounds. Additional in vivo studies would again be required before clinical anti-microbial studies.

The phytoestrogen properties of the tuber of $P$. erosus were established through different in vivo studies on the myometrium. Furthermore, phytoestrogenic effects such as anti-osteoporosis effects on ovariectomized rats and the potential cardio protective effects on volunteers were also observed. Compounds with similar structures to estrogen present in tuber juice are suspected to be the reason for the phytoestrogenic properties, but further studies are required to confirm the phytoconstituent responsible for the effect and molecular mechanism of action. Clinical studies can also be used to explore the phytoestrogenic potential of the tuber.

Initial indications of the cardio protective potential of the P. erosus tuber in human and ex vivo experiments have paved the path to the development of P. erosus as a cardio protective supplement/medication. These initial findings demand more experiments to be carried out to explore its cardio protective properties. Dietary nitrate is suspected to be the reason for the cardio protective properties that again requires further experiments to validate these speculations. The discovery of phytoconstituents responsible would be important to establish the tuber as an intervention for cardio protection through further studies. Similarly, CNSD activity was apparent from different experiments, such as a study on mice models, but more studies must be repeated on different animals before considering this for further clinical studies. The toxicity of the seeds again could be the major bottleneck in in vivo studies before clinical studies, as the toxicity of seeds is reported in different cases. The discovery of the phytochemical that is responsible for CNSD activities could be a step towards harvesting the potential of P. erosus as a CNSD therapeutic.

Broadly, it can be suggested that clinical studies are required for the further development of most of the biological properties of the P. erosus tuber, such as its anti-diabetes, anti-osteoporosis, cardio protective, immune modulation, antioxidant, and anti-aging properties. In the case of the biological properties from the seeds, such as the anticancer, antiviral, antifungal, and CNSD properties, safety studies before human/clinical studies would be required as the toxic effects of the seeds are already reported [23-26].

It is also suggested that $P$. erosus may also have effective anti-obesity properties, which can be discovered in the near future, as the anti-diabetes effects may also help to control weight $[112,113]$. In a study on the anti-diabetes effects of P. erosus, the antiobesity effect was also observed in the mice [62]. In recent research, a study has been conducted to analyze the potential of $P$. erosus tuber fiber in the dysregulation of energy 
metabolism and adiposity in adult male BALB/c mice fed with a high-fat diet. The results support the potential of $P$. erosus tuber fiber as a supplement to minimize the disruption of energy homeostasis and obesity [114]. Research focused on the anti-obesity effects of extracts and/or phytoconstituents from $P$. erosus are also suggested to be carried out in different experiments.

Several compounds, such as dulcitol, gentisic acid, formononetin, kaikasaponin III, pcoumaric acid, and vitexin were known to be present in P. erosus but were not tested/studied in the context of the biological activity of P. erosus (Table 1). These compounds have been known to possess important biological activities [115-120] that are suggested to be explored accordingly in P. erosus.

Recently, dulcitol, which was reported to be present in the seeds of P. erosus, was found to have anticancer activity on cell lines and in in vivo experiments $[119,121]$. Similarly, formononetin, the compound present in the leaves of P. erosus, is also known for its anticancer potential through several possible molecular targets [118,122]. Therefore, the anticancer potential of the leaves from $P$. erosus is suggested to be explored in anticancer experiments.

Recently, wound healing through gentisic acid (a compound present in the leaves) was reported [120], although other biological properties of gentisic acid, such as its neuroprotective, anti-microbial, anti-oxidant, anti-inflammatory, antigenotoxic, and hepatoprotective activities were also reported in the literature [123]. Similarly, vitexin, which is present in the leaves of $P$. erosus, also possesses different biological properties, such as neuro-protective, anticancer, anti-inflammatory, and anti-hyperalgesic properties [115]. As per the presence of both of these active compounds, the associated biological properties, especially the neuro-protective properties, can be explored in future studies of the leaves of $P$. erosus.

It can be concluded that, like its utilization as a food crop, the huge potential of the phytochemicals and the biological properties present in P. erosus are still underutilized. The suggested directions of action from the current review can boost and utilize the potential of $P$. erosus, not only in promoting health, but also in the pharmaceutical and cosmetics industries.

Supplementary Materials: The following supporting information can be downloaded at: https: / / www.mdpi.com/article/10.3390/antiox11010058/s1, Table S1: Volatile and other phytochemicals identified in P. erosus.

Author Contributions: H.-J.L., V.J., and S.C. designed the study. V.J., and S.C. wrote the manuscript; H.-J.L. reviewed the manuscript intensively; H.-J.L., V.J., and S.C. edited the manuscript. All authors have read and agreed to the published version of the manuscript.

Funding: This work was supported by Korea Institute of Planning and Evaluation for Technology in Food, Agriculture and Forestry (IPET) through High Value-Added Food Technology development Program, funded by Ministry of Agriculture, Food and Rural Affairs (MAFRA)(grant number 32102404-1-HD020).

Conflicts of Interest: The authors declare no conflict of interest.

\section{References}

1. Suleman, M.; Khan, A.; Baqi, A.; Kakar, M.S.; Ayub, M. 2. Antioxidants, its role in preventing free radicals and infectious diseases in human body. Pure Appl. Biol. 2019, 8, 380-388. [CrossRef]

2. Grosso, G. Dietary antioxidants and prevention of non-communicable diseases. Antioxidants 2018, 7, 94. [CrossRef]

3. Forman, H.J.; Zhang, H. Targeting oxidative stress in disease: Promise and limitations of antioxidant therapy. Nat. Rev. Drug Discov. 2021, 20, 689-709. [CrossRef]

4. Chung, I.M.; Paudel, N.; Kim, S.-H.; Yu, C.Y.; Ghimire, B.K. The Influence of Light Wavelength on Growth and Antioxidant Capacity in Pachyrhizus erosus (L.) Urban. J. Plant Growth Regul. 2019, 39, 296-312. [CrossRef]

5. Lee, A.; Kim, G.-N.; Kim, H.-O.; Song, W.; Roh, S.-S. Antioxidant activity and melanin inhibitory effects of yambean (Pachyrhizus erosus) extract. Korea J. Herbol. 2017, 32, 57-64.

6. Lukitaningsih, E. Bioactive compounds in bengkoang (Pachyrhizus erosus) as antioxidant and tyrosinase inhibiting agents. Indones. J. Pharm. 2014, 25, 68. [CrossRef] 
7. Siregar, I.D.; Kusuma, H.S.W.; Widowati, W.; Marpaung, H.H.; Ferdinand, S.; Fachrial, E.; Lister, I.N.E. Antioxidant and antityrosinase activities of ethanolic pachyrhizuserosus peel and tuber extract. Maj. Kedokt. Bdg. 2019, 51, 75-81. [CrossRef]

8. Abid, M.; Hrishikeshavan, H.; Asad, M. Pharmacological evaluation of Pachyrrhizus erosus (L.) seeds for central nervous system depressant activity. Indian J. Physiol. Pharmacol. 2006, 50, 143.

9. Phrutivorapongkul, A.; Lipipun, V.; Ruangrungsi, N.; Watanabe, T.; Ishikawa, T. Studies on the constituents of seeds of Pachyrrhizus erosus and their anti herpes simplex virus (HSV) activities. Chem. Pharm. Bull. 2002, 50, 534-537. [CrossRef]

10. Kardono, L.B.; Tsauri, S.; Pezzuto, J.M.; Kinghorn, A.D.; Padmawinata, K. Cytotoxic isoflavonoids of pachyrrhius erosus seeds. J. Kim. Terap. Indones. (Indones. J. Appl.Chem.) 1994, 4, $2-5$.

11. Guo, J.-L.; Cheng, Y.-L.; Qiu, Y.; Shen, C.-H.; Yi, B.; Peng, C. Purification and characterization of a novel type I ribosome inactivating protein, pachyerosin, from Pachyrhizus erosus seeds, and preparation of its immunotoxin against human hepatoma cells. Planta Med. 2014, 80, 896-901. [CrossRef]

12. Baroroh, H.N.; Nugroho, A.E.; Lukitaningsih, E.; Nurrochmad, A. Immune-enhancing effect of bengkoang (Pachyrhizus erosus (L.) Urban) fiber fractions on mouse peritoneal macrophages, lymphocytes, and cytokines. J. Nat.Sci. Biol. Med. 2021, 12, 84.

13. Necha, L.L.B.; Baños, S.B.; Luna, L.B.; Suárez, F.J.L.G.; Solano, D.A.; Chilpa, R.R. Antifungal activity of seed powders, extracts, and secondary metabolites of Pachyrhizus erosus (L.) urban (Fabaceae) against three postharvest fungi. Rev. Mex. Fitopatol. 2004, $22,356-361$.

14. Nurrochmad, A.; Leviana, F.; Wulancarsari, C.G.; Lukitaningsih, E. Phytoestrogens of Pachyrhizus erosus prevent bone loss in an ovariectomized rat model of osteoporosis. Int. J. Phytomed. 2010, 2, 363-372.

15. Baroroh, H.N.; Nugroho, A.E.; Lukitaningsih, E.; Nurrochmad, A. Water-Soluble Fiber from Bengkoang (Pachyrhizus erosus (L.) Urban) Tuber Modulates Immune System Activity in Male Mice. Sci. Pharm. 2020, 88, 34. [CrossRef]

16. Lukitaningsih, E.; Holzgrabe, U. A New Compound (8,9)-Furanyl-Pterocarpan-3-Ol Used for Standardization of Bengkuang (Pachyrhizus erosus) Extract as Sunscreen and Skin Whitening Agent. Indones. J. Cancer Chemoprev. 2019, 10, 60-70. [CrossRef]

17. Sujono, T.A.; Nurrochmad, A.; Lukitaningsih, E.; Nugroho, A.E. Immunomodulatory Effect of Methanolic Extract and Ethyl Acetate Fraction of Bengkoang (Pachyrhizus erosus (L.) Urban) Tuber in Mice. Pharmacogn. J. 2021, 13, 59-65. [CrossRef]

18. Kim, S.-K.; Choi, H.-J.; Won, J.-H.; Park, J.-H.; Lee, I.-J.; Park, S.-Y. Introduction of yam bean (Pachyrhizus spp.) in Korea. Korean J. Plant Resour. 2009, 22, 546-551.

19. Sørensen, M. Yam Bean: Pachyrhizus DC.-Promoting the Conservation and Use of Underutilized and Neglected Crops. 2; Bioversity International: Rome, Italy, 1996; Volume 2.

20. Naskar, S. Progress and status of yam bean research in India. In Proceedings of the 15th Triennial Symposium Of The International Society For Tropical Root Crops, Lima, Peru, 2-6 November 2009; pp. 2-6.

21. Jean, N.; Patrick, R.; Phenihas, T.; Rolland, A.; Placide, R.; Robert, M.O.; Silver, T.; Vestine, K.; Evrard, K.; Grüneberg, W.J Evaluation of performance of introduced yam bean (Pachyrhizus spp.) in three agro-ecological zones of Rwanda. Trop. Plant Biol. 2017, 10, 97-109. [CrossRef]

22. Montagnac, J.A.; Davis, C.R.; Tanumihardjo, S.A. Processing techniques to reduce toxicity and antinutrients of cassava for use as a staple food. Compr. Rev. Food Sci. Food Saf. 2009, 8, 17-27. [CrossRef]

23. Narongchai, P.; Narongchai, S.; Thampituk, S. The first fatal case of yam bean and rotenone toxicity in Thailand. J. Med. Assoc. Thail. 2005, 88, 984-986.

24. Hung, Y.M.; Hung, S.Y.; Olson, K.; Chou, K.J.; Lin, S.L.; Chung, H.M.; Tung, C.N.; Chang, J.C. Yam bean seed poisoning mimicking cyanide intoxication. Intern. Med. J. 2007, 37, 130-132. [CrossRef] [PubMed]

25. Fu, P.-K.; Wang, P.-Y. Toxic leukoencephalopathy due to yam bean seeds poisoning. Neurologist 2012, 18, 199-201. [CrossRef] [PubMed]

26. Gao, H.H.; Li, J.Y.; Geng, L.; Liu, X.J.; Yue, H.W.; Li, W.D.; Zheng, X.Q. Investigation of food poisoning caused by seeds of Pachyrhizus erosus. Occup. Health 2009, 25, 1050-1051.

27. Lim, T. Pachyrhizus erosus. In Edible Medicinal and Non-Medicinal Plants; Springer: Berlin/Heidelberg, Germany, 2016 ; pp. 465-481.

28. Santos, A.; Cavalcanti, M.; Coelho, L. Chemical composition and nutritional potential of yam bean seeds (Pachyrhizus erosus L. Urban). Plant Foods Hum. Nutr. 1996, 49, 35-41. [CrossRef]

29. Catteau, L.; Lautié, E.; Koné, O.; Coppée, M.; Hell, K.; Pomalegni, C.B.; Quetin-Leclercq, J.l. Degradation of rotenone in yam bean seeds (Pachyrhizus sp.) through food processing. J. Agric. Food Chem. 2013, 61, 11173-11179. [CrossRef]

30. Noman, A.; Hoque, M.; Haque, M.; Pervin, F.; Karim, M. Nutritional and anti-nutritional components in Pachyrhizus erosus L. tuber. Food Chem. 2007, 102, 1112-1118. [CrossRef]

31. Morales-Arellano, G.Y.; Chagolla-López, A.; Paredes-López, O.; de la Rosa, A.P.B. Characterization of yam bean (Pachyrhizus erosus) proteins. J. Agric. Food Chem. 2001, 49, 1512-1516. [CrossRef]

32. Broadbent, J.; Shone, G. The composition of Pachyrrhizus erosus (yam bean) seed oil. J. Sci. Food Agric. 1963, $14,524-527$. [CrossRef]

33. Grüneberg, W.; Goffman, F.; Velasco, L. Characterization of yam bean (Pachyrhizus spp.) seeds as potential sources of high palmitic acid oil. J. Am. Oil Chem. Soc. 1999, 76, 1309-1312. [CrossRef]

34. Knothe, G.; Razon, L.F.; Madulid, D.A.; Agoo, E.M.G.; de Castro, M.E.G. Methyl esters (biodiesel) from Pachyrhizus erosus seed oil. Biofuels 2018, 9, 449-454. [CrossRef] 
35. YAHARA, S.; IRINO, N.; TAKAOKA, T.; NOHARA, T. Studies on the constituents of Pachyrhizus erosus. Nat. Med. 1994, 48, 312-313.

36. Lautié, E.; Rozet, E.; Hubert, P.; Vandelaer, N.; Billard, F.; Zum Felde, T.; Grüneberg, W.J.; Quetin-Leclercq, J. Fast method for the simultaneous quantification of toxic polyphenols applied to the selection of genotypes of yam bean (Pachyrhizus sp.) seeds. Talanta 2013, 117, 94-101. [CrossRef] [PubMed]

37. Lukitaningsih, E.; Bahi, M.; Holzgrabe, U. Tyrosinase inhibition type of isolated compounds obtained from Pachyrhizus erosus. Aceh Int. J. Sci. Technol. 2013, 2, 98-102. [CrossRef]

38. Estrella-Parra, E.A.; Gomez-Verjan, J.C.; González-Sánchez, I.; Vázquez-Martínez, E.R.; Vergara-Castañeda, E.; Cerbón, M.A.; Alavez-Solano, D.; Reyes-Chilpa, R. Rotenone isolated from Pachyrhizus erosus displays cytotoxicity and genotoxicity in K562 cells. Nat. Prod. Res. 2014, 28, 1780-1785. [CrossRef]

39. Minh, T.T.; Toan, H.K.; Anh, H.T.L.; Huong, T.T.; Do, T.T.; Hoang, V.D. Chemical Constituents from the Leaves of Pachyrhizus erosus Collected in Vietnam. Chem. Pharm. Bull. 2021, 69, 1136-1139. [CrossRef]

40. Estrella-Parra, E.A.; Gómez-Verjan, J.C.; Céspedes, C.L.; Alarcón, J.; Cano-Santana, Z.; Reyes-García, A.; Cerbón-Cervantes, M.A.; Reyes-Chilpa, R. Volatile organic compounds from Pachyrhizus ferrugineus and Pachyrhizus erosus (Fabaceae) leaves. Boletín Caribe Plantas Med. Aromáticas 2016, 15, 175-181.

41. Primiani, C.N.; Lestari, U.; Amin, M.; Sumitro, S.B. The Dynamics Of Daidzein Chemical Compound From Yam Tuber (Pachyrhizus erosus) Tuber And Its Potential In Myometrium. Berk. Penelit. Hayati 2013, 18, 122-128. [CrossRef]

42. Zhu, L.; Ni, Z.; Luo, X.; Wang, X. Advance of antioxidants in asthma treatment. World J. Respirol. 2017, 7, 17-28. [CrossRef]

43. Bhandari, R.; Khanna, G.; Kuhad, A. Prostate cancer and food-based antioxidants in India as plausible therapeutics. In Cancer; Elsevier: Amsterdam, The Netherlands, 2021; pp. 203-217.

44. Kaneto, H.; Kajimoto, Y.; Miyagawa, J.-i.; Matsuoka, T.-a.; Fujitani, Y.; Umayahara, Y.; Hanafusa, T.; Matsuzawa, Y.; Yamasaki, Y.; Hori, M. Beneficial effects of antioxidants in diabetes: Possible protection of pancreatic beta-cells against glucose toxicity. Diabetes 1999, 48, 2398-2406. [CrossRef]

45. Kusumawati, I.; Indrayanto, G. Natural antioxidants in cosmetics. In Studies in Natural Products Chemistry; Elsevier: Amsterdam, The Netherlands, 2013; Volume 40, pp. 485-505.

46. Masaki, H. Role of antioxidants in the skin: Anti-aging effects. J. Dermatol. Sci. 2010, 58, 85-90. [CrossRef]

47. Jaiswal, V.; Park, M.; Lee, H.-J. Comparative Transcriptome Analysis of the Expression of Antioxidant and Immunity Genes in the Spleen of a Cyanidin 3-O-Glucoside-Treated Alzheimer's Mouse Model. Antioxidants 2021, 10, 1435. [CrossRef]

48. Choi, E.J.; Kim, G.H. The antioxidant activity of daidzein metabolites, O-desmethylangolensin and equol, in HepG2 cells. Mol. Med. Rep. 2014, 9, 328-332. [CrossRef]

49. Chen, L.; Zhang, B.; Shan, S.; Zhao, X. Neuroprotective effects of vitexin against isoflurane-induced neurotoxicity by targeting the TRPV1 and NR2B signaling pathways. Mol. Med. Rep. 2016, 14, 5607-5613. [CrossRef] [PubMed]

50. Malar, D.S.; Prasanth, M.I.; Shafreen, R.B.; Balamurugan, K.; Devi, K.P. Grewia tiliaefolia and its active compound vitexin regulate the expression of glutamate transporters and protect Neuro-2a cells from glutamate toxicity. Life Sci. 2018, 203, 233-241. [CrossRef] [PubMed]

51. Malar, D.S.; Suryanarayanan, V.; Prasanth, M.I.; Singh, S.K.; Balamurugan, K.; Devi, K.P. Vitexin inhibits A $\beta 25-35$ induced toxicity in Neuro-2a cells by augmenting Nrf-2/HO-1 dependent antioxidant pathway and regulating lipid homeostasis by the activation of LXR- $\alpha$. Toxicol. Vitr. 2018, 50, 160-171. [CrossRef] [PubMed]

52. Yang, H.; Huang, J.; Mao, Y.; Wang, L.; Li, R.; Ha, C. Vitexin alleviates interleukin-1 $\beta$-induced inflammatory responses in chondrocytes from osteoarthritis patients: Involvement of HIF-1 $\alpha$ pathway. Scand. J. Immunol. 2019, 90, e12773. [CrossRef]

53. Hider, R.C.; Liu, Z.D.; Khodr, H.H. Metal chelation of polyphenols. Methods Enzymol. 2001, 335, $190-203$.

54. Perron, N.R.; Brumaghim, J.L. A review of the antioxidant mechanisms of polyphenol compounds related to iron binding. Cell Biochem. Biophys. 2009, 53, 75-100. [CrossRef]

55. Cho, N.; Shaw, J.; Karuranga, S.; Huang, Y.; da Rocha Fernandes, J.; Ohlrogge, A.; Malanda, B. IDF Diabetes Atlas: Global estimates of diabetes prevalence for 2017 and projections for 2045. Diabetes Res. Clin. Pract. 2018, 138, 271-281. [CrossRef]

56. Jaiswal, V.; Negi, A.; Pal, T. A review on current advances in machine learning based diabetes prediction. Prim. Care Diabetes 2021, 15, 435-443. [CrossRef]

57. Bain, S.C.; Cummings, M.H.; McKay, G.A. Multidisciplinary Approach to Management and Care of Patients with Type 2 Diabetes Mellitus. Diabetes 2019, 7, 73-81.

58. Negi, A.; Jaiswal, V. A first attempt to develop a diabetes prediction method based on different global datasets. In Proceedings of the 2016 Fourth International Conference on Parallel, Distributed and Grid Computing (PDGC), Waknaghat, India, 22-24 December 2016; pp. 237-241.

59. Teoh, S.L.; Das, S. Phytochemicals and their effective role in the treatment of diabetes mellitus: A short review. Phytochem. Rev. 2018, 17, 1111-1128. [CrossRef]

60. Park, C.J.; Han, J.-S. Hypoglycemic effect of jicama (Pachyrhizus erosus) extract on streptozotocin-induced diabetic mice. Prev. Nutr. Food Sci. 2015, 20, 88. [CrossRef]

61. Park, C.J.; Lee, H.-A.; Han, J.-S. Jicama (Pachyrhizus erosus) extract increases insulin sensitivity and regulates hepatic glucose in C57BL/Ksj-db/db mice. J. Clin. Biochem. Nutr. 2015, 58, 15-59. [CrossRef] [PubMed] 
62. Santoso, P.; Amelia, A.; Rahayu, R. Jicama (Pachyrhizus erosus) fiber prevents excessive blood glucose and body weight increase without affecting food intake in mice fed with high-sugar diet. J. Adv. Vet. Anim. Res. 2019, 6, 222. [CrossRef] [PubMed]

63. Santoso, P.; Maliza, R.; Insani, S.J.; Fadhila, Q.; Rahayu, R. Preventive effect of jicama (Pachyrhizus erosus) fiber against diabetes development in mice fed with high-fat diet. J. Appl. Pharm. Sci. 2021, 11, 137-143.

64. Santoso, P.; Maliza, R.; Rahayu, R.; Amelia, A. Pancreoprotective Effect of Jicama (Pachyrhizus erosus, Fabaceae) Fiber against High-Sugar Diet in Mice. Open Access Maced. J. Med. Sci. 2020, 8, 326-332. [CrossRef]

65. Yuniritha, E.; Avelia, A. Effectiveness of Jicama Probiotic Yoghurt (Pachyrhizus erosus) on Blood Glucose in Diabetic Mice. KnE Life Sci. 2019, 2019, 250-261. [CrossRef]

66. Stevenson, D.G.; Jane, J.l.; Inglett, G.E. Characterisation of jícama (Mexican potato)(Pachyrhizus erosus L. Urban) starch from taproots grown in USA and Mexico. Starch-Stärke 2007, 59, 132-140. [CrossRef]

67. Li, K.; Zhang, L.; Xue, J.; Yang, X.; Dong, X.; Sha, L.; Lei, H.; Zhang, X.; Zhu, L.; Wang, Z. Dietary inulin alleviates diverse stages of type 2 diabetes mellitus via anti-inflammation and modulating gut microbiota in db/db mice. Food Funct. 2019, 10, 1915-1927. [CrossRef] [PubMed]

68. Wang, L.; Yang, H.; Huang, H.; Zhang, C.; Zuo, H.-X.; Xu, P.; Niu, Y.-M.; Wu, S.-S. Inulin-type fructans supplementation improves glycemic control for the prediabetes and type 2 diabetes populations: Results from a GRADE-assessed systematic review and dose-response meta-analysis of 33 randomized controlled trials. J. Transl. Med. 2019, 17, 410. [CrossRef] [PubMed]

69. Widyarman, A.D.; Nurdiamah, E.; Soetedjo, N.N.M. Effects of Bengkoang (Pachyrhizus erosus (L.) Urb Juice in Hampering Blood Glucose in Rat Models. Althea Med. J. 2014, 1, 25-29. [CrossRef]

70. Bray, F.; Ferlay, J.; Soerjomataram, I.; Siegel, R.L.; Torre, L.A.; Jemal, A. Global cancer statistics 2018: GLOBOCAN estimates of incidence and mortality worldwide for 36 cancers in 185 countries. CA Cancer J. Clin. 2018, 68, 394-424. [CrossRef]

71. Choudhari, A.S.; Mandave, P.C.; Deshpande, M.; Ranjekar, P.; Prakash, O. Phytochemicals in cancer treatment: From preclinical studies to clinical practice. Front. Pharmacol. 2020, 10, 1614. [CrossRef] [PubMed]

72. Rizeq, B.; Gupta, I.; Ilesanmi, J.; AlSafran, M.; Rahman, M.M.; Ouhtit, A. The power of phytochemicals combination in cancer chemoprevention. J. Cancer 2020, 11, 4521. [CrossRef]

73. Lee, K.W.; Bode, A.M.; Dong, Z. Molecular targets of phytochemicals for cancer prevention. Nat. Rev. Cancer 2011, 11, 211-218. [CrossRef]

74. Howes, M.-J.R.; Simmonds, M.S. The role of phytochemicals as micronutrients in health and disease. Curr. Opin. Clin. Nutr. Metab. Care 2014, 17, 558-566. [CrossRef]

75. Kotecha, R.; Takami, A.; Espinoza, J.L. Dietary phytochemicals and cancer chemoprevention: A review of the clinical evidence. Oncotarget 2016, 7, 52517. [CrossRef]

76. Alam, A.; Jaiswal, V.; Akhtar, S.; Jayashree, B.; Dhar, K. Isolation of isoflavones from Iris kashmiriana Baker as potential anti proliferative agents targeting NF-kappaB. Phytochemistry 2017, 136, 70-80. [CrossRef]

77. Gerhäuser, C.; Mar, W.; Lee, S.K.; Suh, N.; Luo, Y.; Kosmeder, J.; Luyengi, L.; Fong, H.H.; KingHorn, A.D.; Moriarty, R.M. Rotenoids mediate potent cancer chemopreventive activity through transcriptional regulation of ornithine decarboxylase. Nat. Med. 1995, 1, 260-266. [CrossRef] [PubMed]

78. Kardono, L.; Tsauri, S.; Padmawinata, K.; Pezzuto, J.; Kinghorn, A. Cytotoxic constituents of the seeds of Pachyrrhizus erosus Planta Med. 1990, 56, 673-674. [CrossRef]

79. Bak, D.-h.; Kang, S.H.; Park, C.-h.; Chung, B.Y.; Bai, H.-W. A novel radiolytic rotenone derivative, rotenoisin A, displays potent anticarcinogenic activity in breast cancer cells. J. Radiat. Res. 2021, 62, 249-258. [CrossRef]

80. Badaboina, S.; Bai, H.-W.; Na, Y.H.; Park, C.-H.; Kim, T.H.; Lee, T.-H.; Chung, B.Y. Novel radiolytic rotenone derivative, rotenoisin B with potent anti-carcinogenic activity in hepatic cancer cells. Int. J. Mol. Sci. 2015, 16, 16806-16815. [CrossRef] [PubMed]

81. Demaria, O.; Cornen, S.; Daëron, M.; Morel, Y.; Medzhitov, R.; Vivier, E. Harnessing innate immunity in cancer therapy. Nature 2019, 574, 45-56. [CrossRef]

82. Jaiswal, V.; Cho, Y.-I.; Lee, H.-J. Preliminary Study to Explore the Immune-Enhancement Mechanism of Platycodon grandiflorus Extract through Comparative Transcriptome Analysis. Appl. Sci. 2021, 11, 226. [CrossRef]

83. Muraille, E. The unspecific side of acquired immunity against infectious disease: Causes and consequences. Front. Microbiol. 2016, 6, 1525. [CrossRef]

84. Kumalasari, I.D.; Nishi, K.; Harmayani, E.; Raharjo, S.; Sugahara, T. Effect of bengkoang (Pachyrhizus erosus) fiber extract on murine macrophage-like J774. 1 cells and mouse peritoneal macrophages. J. Funct. Foods 2013, 5, 582-589. [CrossRef]

85. Ouyang, W.; Rutz, S.; Crellin, N.K.; Valdez, P.A.; Hymowitz, S.G. Regulation and functions of the IL-10 family of cytokines in inflammation and disease. Annu. Rev. Immunol. 2011, 29, 71-109. [CrossRef]

86. Kumalasari, I.D.; Nishi, K.; Harmayani, E.; Raharjo, S.; Sugahara, T. Immunomodulatory activity of Bengkoang (Pachyrhizus erosus) fiber extract in vitro and in vivo. Cytotechnology 2014, 66, 75-85. [CrossRef]

87. Ganjhu, R.K.; Mudgal, P.P.; Maity, H.; Dowarha, D.; Devadiga, S.; Nag, S.; Arunkumar, G. Herbal plants and plant preparations as remedial approach for viral diseases. Virusdisease 2015, 26, 225-236. [CrossRef] [PubMed]

88. Moghadamtousi, S.Z.; Nikzad, S.; Kadir, H.A.; Abubakar, S.; Zandi, K. Potential antiviral agents from marine fungi: An overview. Mar. Drugs 2015, 13, 4520-4538. [CrossRef] [PubMed] 
89. Oyero, O.G.; Toyama, M.; Mitsuhiro, N.; Onifade, A.A.; Hidaka, A.; Okamoto, M.; Baba, M. Selective inhibition of hepatitis c virus replication by Alpha-zam, a Nigella sativa seed formulation. Afr. J. Tradit. Complement. Altern. Med. 2016, 13, 144-148. [CrossRef] [PubMed]

90. Attia, Y.A.; Alagawany, M.M.; Farag, M.R.; Alkhatib, F.M.; Khafaga, A.F.; Abdel-Moneim, A.-M.E.; Asiry, K.A.; Mesalam, N.M.; Shafi, M.E.; Al-Harthi, M.A. Phytogenic products and phytochemicals as a candidate strategy to improve tolerance to coronavirus. Front. Vet. Sci. 2020, 7, 783. [CrossRef] [PubMed]

91. Ben-Shabat, S.; Yarmolinsky, L.; Porat, D.; Dahan, A. Antiviral effect of phytochemicals from medicinal plants: Applications and drug delivery strategies. Drug Deliv. Transl. Res. 2020, 10, 354-367. [CrossRef] [PubMed]

92. Anand, A.V.; Balamuralikrishnan, B.; Kaviya, M.; Bharathi, K.; Parithathvi, A.; Arun, M.; Senthilkumar, N.; Velayuthaprabhu, S.; Saradhadevi, M.; Al-Dhabi, N.A. Medicinal Plants, Phytochemicals, and Herbs to Combat Viral Pathogens Including SARS-CoV-2. Molecules 2021, 26, 1775. [CrossRef] [PubMed]

93. Ahmad, A.; Molepo, J.; Patel, M. Challenges in the development of antifungal agents against Candida: Scope of phytochemical research. Curr. Pharm. Des. 2016, 22, 4135-4150. [CrossRef]

94. Bing, H.; Xiaoming, Y.; Yujuan, L.; Minghuang, C.; Jianhua, C.; Lijun, S. Isolation, purification and partial characterization of an antifungal protein PaAFP from seeds of Pachyrrhizus erosus. Zhongguo Sheng Wu Hua Xue Yu Fen Zi Sheng Wu Xue Bao = Chin. J. Biochem. Mol. Biol. 1999, 15, 1006-1008.

95. Song, X.; Wang, J.; Wu, F.; Li, X.; Teng, M.; Gong, W. cDNA cloning, functional expression and antifungal activities of a dimeric plant defensin SPE10 from Pachyrrhizus erosus seeds. Plant Mol. Biol. 2005, 57, 13-20. [CrossRef]

96. Song, X.; Zhou, Z.; Wang, J.; Wu, F.; Gong, W. Purification, characterization and preliminary crystallographic studies of a novel plant defensin from Pachyrrhizus erosus seeds. Acta Crystallogr. Sect. D Biol. Crystallogr. 2004, 60, 1121-1124. [CrossRef]

97. Shibu, M.A.; Kuo, W.-W.; Kuo, C.-H.; Day, C.-H.; Shen, C.-Y.; Chung, L.-C.; Lai, C.-H.; Pan, L.-F.; Padma, V.V.; Huang, C.-Y. Potential phytoestrogen alternatives exert cardio-protective mechanisms via estrogen receptors. BioMedicine 2017, 7, 11. [CrossRef] [PubMed]

98. Lagari, V.S.; Levis, S. Phytoestrogens in the prevention of postmenopausal bone loss. J. Clin. Densitom. 2013, 16, 445-449. [CrossRef] [PubMed]

99. Primiani, C.N. The phytoestrogenic potential of yam bean (Pachyrhizus erosus) on ovarian and uterine tissue structure of premenopausal mice. Biol. Med. Nat. Prod. Chem. 2015, 4, 5-9. [CrossRef]

100. Hadiningsih, E.F.; Ardela, M.P.; Nurseta, T.; Noorhamdani; Winarsih, S.; Anita, K.W.; Angelina, A. The effect of bengkuang (Pachyrhizus erosus) ethanol extract on the number of ovarian follicles, amount of epithelium and endometrium stroma cells in DMPA-treated Rattus norvegicus. AIP Conf. Proc. 2020, 2231, 040015.

101. Mensah, G.A.; Roth, G.A.; Fuster, V. The global burden of cardiovascular diseases and risk factors: 2020 and beyond. J. Am. Coll. Cardiol. 2019, 74, 2529-2532. [CrossRef]

102. Thaptimthong, T.; Kasemsuk, T.; Sibmooh, N.; Unchern, S. Platelet inhibitory effects of juices from Pachyrhizus erosus L. root and Psidium guajava L. fruit: A randomized controlled trial in healthy volunteers. BMC Complement. Altern. Med. 2016, 16, 269. [CrossRef]

103. Khotijah, A.A.; Prabowo, R.; Pramaningtyas, M.D. The measurement of malondialdehyde level in heart tissue of hyperlipidemic rats after intervention of combination of Jicama (Pachyrhizus erosus) concentrate and kefir milk as a syn. J. Hypertens. 2021, 39, e164-e165. [CrossRef]

104. Welcome, M.O. Blood brain barrier inflammation and potential therapeutic role of phytochemicals. Pharma Nutr. 2020, $11,100177$. [CrossRef]

105. Pertiwi, R.; Hanuun, A.; Kurniawati, N.; Siti Khodijah, P.; Fita Lestari, D.; Fitriani, D.; Notriawan, D. The effect of Raphanus sativus and Pachyrhizus erosus juice combination on the ethanol-induced gastric of mice. Pharmaciana 2021, 11, 312-320. [CrossRef]

106. Liu, J.; Wang, J.; Shi, Y.; Su, W.; Chen, J.; Zhang, Z.; Wang, G.; Wang, F. Short chain fatty acid acetate protects against ethanolinduced acute gastric mucosal lesion in mice. Biol. Pharm. Bull. 2017, 40, 1439-1446. [CrossRef]

107. Bañez, S.E.S. Insecticidal effects of arrowhead (Syngonium podophyllum) \& jicama (Pachyrhizus erosus) against odorous house ants (Tapinoma sessile). IAMURE Int. J. Ecol. Conserv. 2016, 20, 1.

108. Basukriadi, A.; Wilkins, R.M. Oviposition deterrent activities of Pachyrhizus erosus seed extract and other natural products on Plutella xylostella (Lepidoptera: Plutellidae). J. Insect Sci. 2014, 14, 244. [CrossRef]

109. Yongkhamcha, B.; Indrapichate, K. Insecticidal efficacy of mintweed, yam bean and celery seed extracts on Aedes aegypti L. Int. J. Agric. Sci. 2012, 4, 207.

110. Safitri, Y. Pengaruh pemberian sari pati bengkuang (Pachyrhizus erosus) terhadap kadar glukosa darah pada penderita diabetes mellitus tipe II usia 40-50 tahun di kelurahan bangkinang wilayah kerja puskesmas bangkinang kota tahun 2018. PREPOTIF J. Kesehat. Masy. 2018, 2, 14-26.

111. Setyawati, A.; Yamauchi, K.; Mitsunaga, T. Potential of medicinal plants extractives as anti-melanogenesis ingredients. Rev. Agric. Sci. 2018, 6, 46-60. [CrossRef]

112. Lu, Y.; Levin, G.; Donner, T. Tagatose, a new antidiabetic and obesity control drug. Diabetes Obes. Metab. 2008, 10, 109-134 [CrossRef] [PubMed]

113. Hossain, M.K.; Dayem, A.A.; Han, J.; Yin, Y.; Kim, K.; Saha, S.K.; Yang, G.-M.; Choi, H.Y.; Cho, S.-G. Molecular mechanisms of the anti-obesity and anti-diabetic properties of flavonoids. Int. J. Mol. Sci. 2016, 17, 569. [CrossRef] [PubMed] 
114. Santoso, P.; Maliza, R.; Insani, S.; Fadhilah, Q. Effect of Jicama (Pachyrhizus erosus) Fiber on Energy Intake and Adipose Tissue Profiles in Mice Fed with High-Fat Diet. In Journal of Physics: Conference Series; IOP Publishing: Bristol, UK, $2021 ;$ p. 012055.

115. He, M.; Min, J.-W.; Kong, W.-L.; He, X.-H.; Li, J.-X.; Peng, B.-W. A review on the pharmacological effects of vitexin and isovitexin. Fitoterapia 2016, 115, 74-85. [CrossRef]

116. Lee, K.-T.; Sohn, I.-C.; Kim, D.-H.; Choi, J.-W.; Kwon, S.-H.; Park, H.-J. Hypoglycemic and hypolipidemic effects of tectorigenin and kaikasaponin III in the streptozotocin-induced diabetic rat and their antioxidant activity in vitro. Arch. Pharmacal Res. 2000, 23, 461-466. [CrossRef]

117. Kiliç, I.; Yeşiloğlu, Y. Spectroscopic studies on the antioxidant activity of p-coumaric acid. Spectrochim. Acta Part A Mol. Biomol. Spectrosc. 2013, 115, 719-724. [CrossRef]

118. Tay, K.-C.; Tan, L.T.-H.; Chan, C.K.; Hong, S.L.; Chan, K.-G.; Yap, W.H.; Pusparajah, P.; Lee, L.-H.; Goh, B.-H. Formononetin: A review of its anticancer potentials and mechanisms. Front. Pharmacol. 2019, 10, 820. [CrossRef]

119. lin Lin, X.; Li, K.; Yang, Z.; Chen, B.; Zhang, T. Dulcitol suppresses proliferation and migration of hepatocellular carcinoma via regulating SIRT1/p53 pathway. Phytomedicine 2020, 66, 153112. [CrossRef]

120. Kim, M.; Kim, J.; Shin, Y.-K.; Kim, K.-Y. Gentisic Acid Stimulates Keratinocyte Proliferation through ERK1/2 Phosphorylation. Int. J. Med. Sci. 2020, 17, 626. [CrossRef]

121. Zhang, Y.; Wang, H.; Li, F.; Xu, X.; Chen, B.; Zhang, T. Inhibitory effects of Dulcitol on rat C6 glioma by regulating autophagy pathway. Nat. Prod. Res. 2020, 34, 1437-1441. [CrossRef] [PubMed]

122. Ong, S.K.L.; Shanmugam, M.K.; Fan, L.; Fraser, S.E.; Arfuso, F.; Ahn, K.S.; Sethi, G.; Bishayee, A. Focus on formononetin: Anticancer potential and molecular targets. Cancers 2019, 11, 611. [CrossRef] [PubMed]

123. Abedi, F.; Razavi, B.M.; Hosseinzadeh, H. A review on gentisic acid as a plant derived phenolic acid and metabolite of aspirin: Comprehensive pharmacology, toxicology, and some pharmaceutical aspects. Phytother. Res. 2020, 34, 729-741. [CrossRef] [PubMed] 